Report of Investigation 2020-5

DEEPWATER MASS-TRANSPORT COMPLEX IN THE UPPER JURASSIC POMEROY ARKOSE MEMBER, NAKNEK FORMATION, CHINITNA BAY, ALASKA: THE DEPOSITIONAL RECORD OF CO-GENETIC SLUMPS AND DEBRIS FLOWS IN A SLOPE TO PROXIMAL BASIN FLOOR SETTING

David L. LePain, Richard G. Stanley, and Kenneth P. Helmold
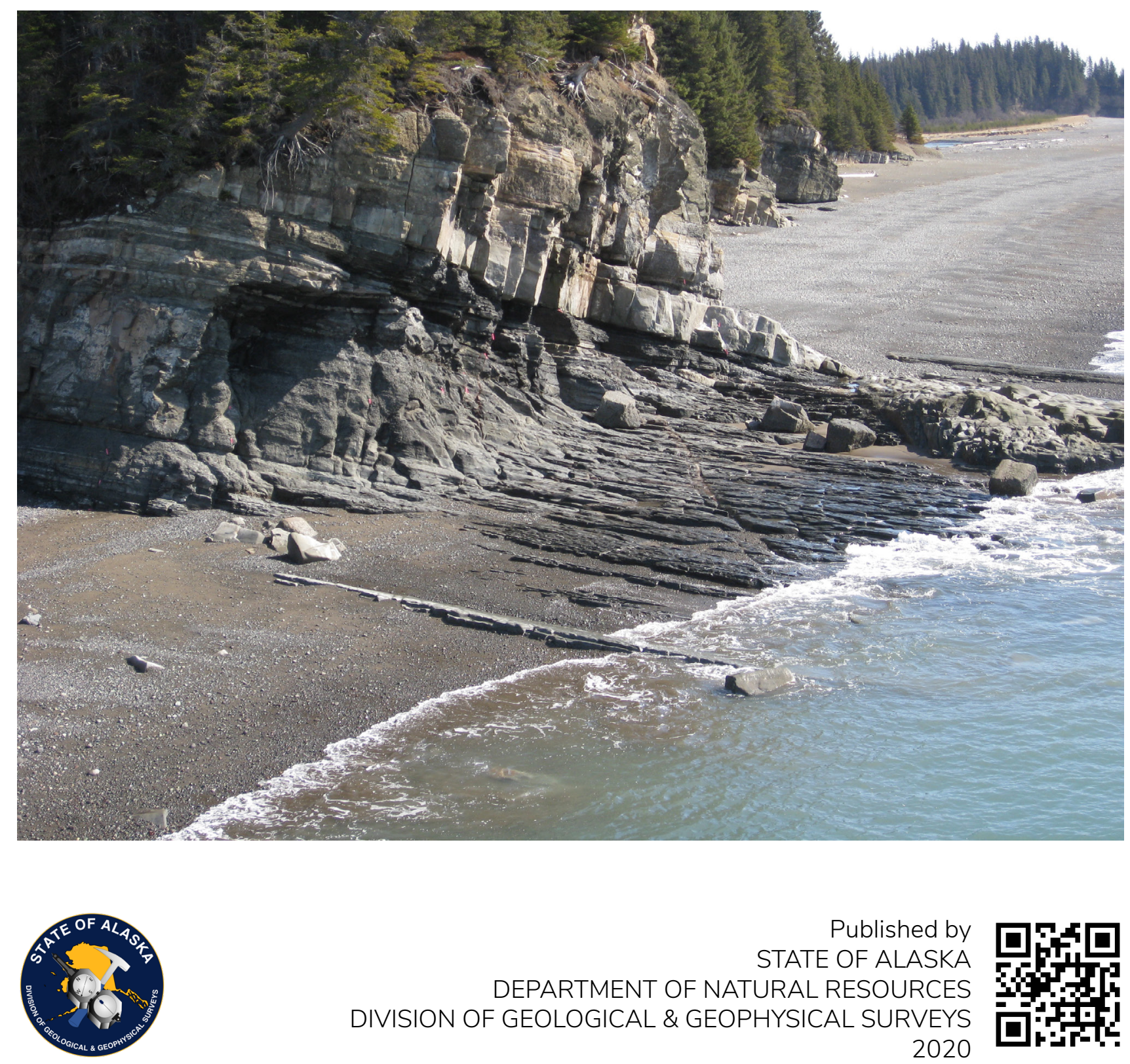

Published by

STATE OF ALASKA

DEPARTMENT OF NATURAL RESOURCES

DIVISION OF GEOLOGICAL \& GEOPHYSICAL SURVEYS

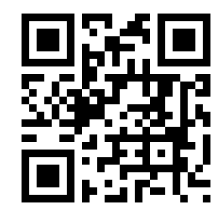


Cover. Low-altitude, oblique air photo showing the lower $25 \mathrm{~m}$ of the section addressed in this report (foreground). The dark gray rocks are mudstones with thinly interbedded sandstone turbidites deposited in a slope to proximal base-of-slope setting. The thick, light colored bed immediately above the mudstones marks the base of a 52.2-m-thick succession of mass-transport deposits and interbedded mudstones, thin-bedded turbidites, and thick-bedded concentrated density flow deposits that continue to the preserved top of the Pomeroy Arkose (rocks visible in upper right, immediately west (left) of the stream valley). Facies relations between these lithotypes provide evidence of the genetic linkage between them and insights into down-slope flow transformations during mass-transport events. See figure 13 for an annotated version of this photograph. View is toward the northeast. 


\section{DEEPWATER MASS-TRANSPORT COMPLEX IN THE UPPER JURASSIC POMEROY ARKOSE MEMBER, NAKNEK FORMATION, CHINITNA BAY, ALASKA: THE DEPOSITIONAL RECORD OF CO-GENETIC SLUMPS AND DEBRIS FLOWS IN A SLOPE TO PROXIMAL BASIN FLOOR SETTING}

David L. LePain, Richard G. Stanley, and Kenneth P. Helmold 


\section{STATE OF ALASKA}

Mike Dunleavy, Governor

\section{DEPARTMENT OF NATURAL RESOURCES}

Corri A. Feige, Commissioner

\section{DIVISION OF GEOLOGICAL \& GEOPHYSICAL SURVEYS}

Steve Masterman, State Geologist and Director

Publications produced by the Division of Geological \&

Geophysical Surveys (DGGS) are available for free download

from the DGGS website (dggs.alaska.gov). Publications on

hard-copy or digital media can be examined or purchased in

the Fairbanks office:

Alaska Division of Geological \& Geophysical Surveys

3354 College Rd., Fairbanks, Alaska 99709-3707

Phone: (907) 451-5010 Fax (907) 451-5050

dggspubs@alaska.gov|dggs.alaska.gov

\section{DGGS publications are also available at:}

Alaska State Library,

Historical Collections \& Talking Book Center

395 Whittier Street

Juneau, Alaska 99811

Alaska Resource Library and Information Services (ARLIS)

3150 C Street, Suite 100

Anchorage, Alaska 99503

\section{Suggested citation:}

LePain, D.L., Stanley, R.G., and Helmold, K.P., 2020, Deepwater mass-transport complex in the Upper Jurassic Pomeroy Arkose Member, Naknek Formation, Chinitna Bay, Alaska: The depositional record of co-genetic slumps and debris flows in a slope to proximal basin floor setting: Alaska Division of Geological \& Geophysical Surveys Report of Investigation 2020-5, 31 p.
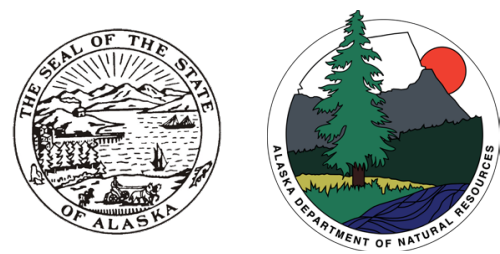


\section{Contents}

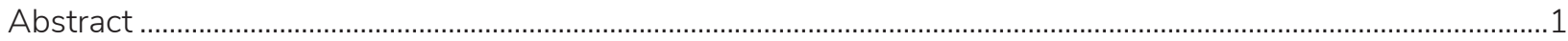

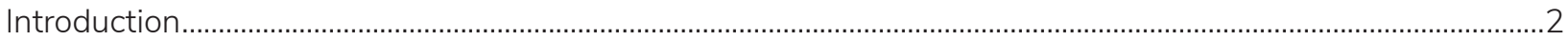

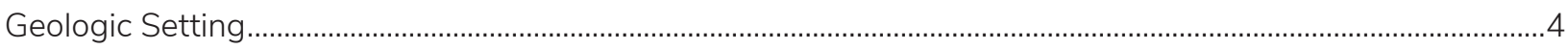

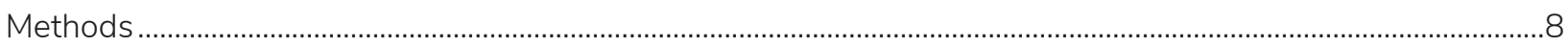

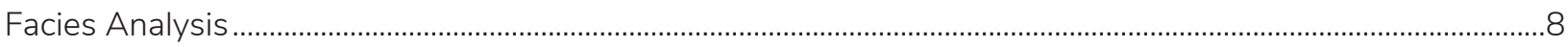

Facies 1 (F1): Thinly Interbedded Sandstone and Mudstone ........................................................................

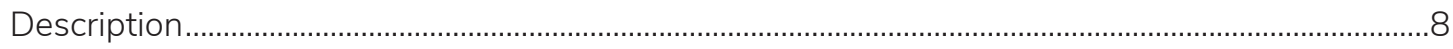

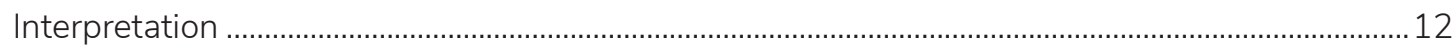

Facies 2 (F2): Massive and Horizontally Laminated Sandstone .................................................................... 12

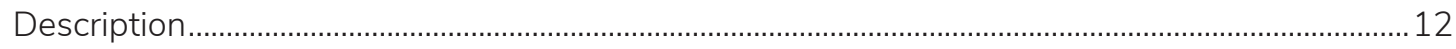

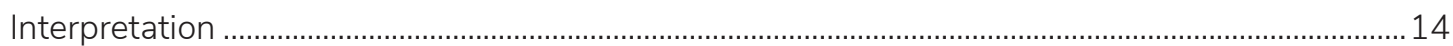

Facies 3 (F3): Massive to Crudely Laminated Pebbly Sandstone ................................................................ 14

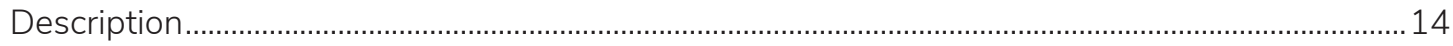

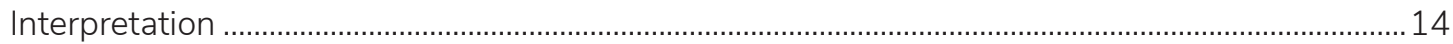

Facies 4 (F4): Clast-Supported, Sandy Pebble and Cobble Conglomerate ................................................16

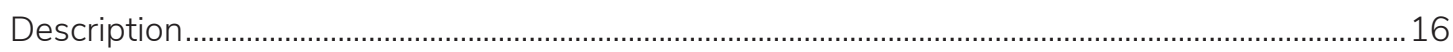

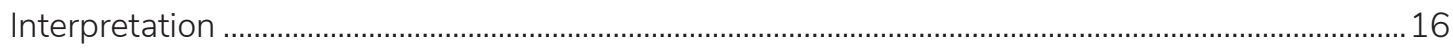

Facies 5 (F5): Clast-Supported, Muddy Pebble and Cobble Conglomerate.................................................16

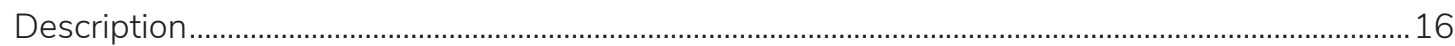

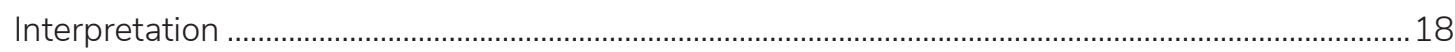

Facies 6 (F6): Matrix-Supported, Pebbly-Cobbly-Bouldery Mudstone ………...........................................18

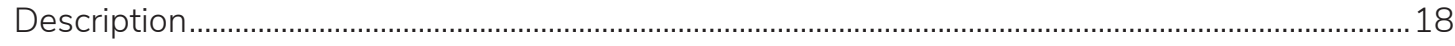

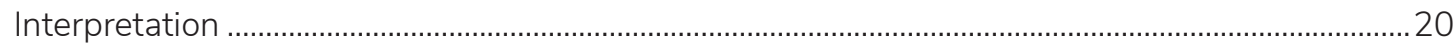

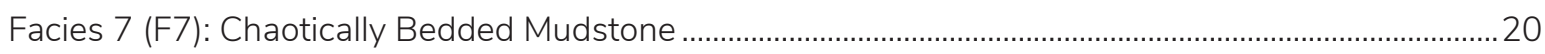

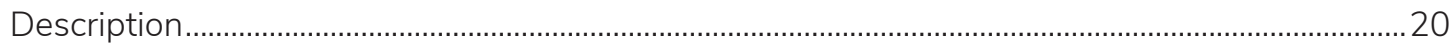

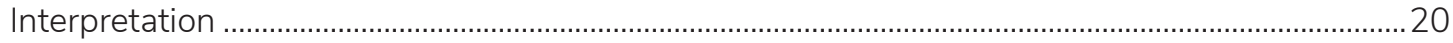

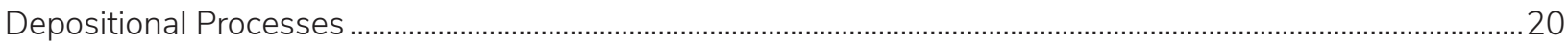

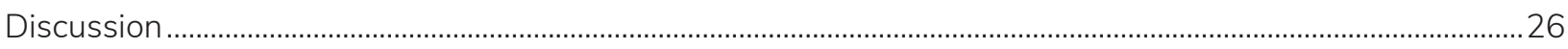

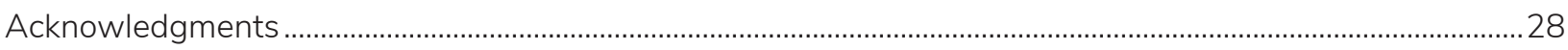

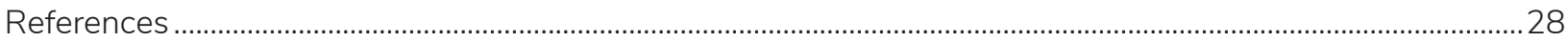

Figures

Figure 1. Geologic map of the Chinitna Bay area in the lower Cook Inlet region ....................................................

Figure 2. Generalized stratigraphic column for Cook Inlet basin ..........................................................................

Figure 3. Low-altitude, oblique aerial photographs showing the upper $63.2 \mathrm{~m}$ of the Pomeroy

Arkose Member at its type section along the north shore of Chinitna Bay..........................................................

Figure 4. Composite measured stratigraphic section through the upper $63.2 \mathrm{~m}$ of the Pomeroy Arkose Member, Naknek Formation ..................................................................................................................

Figure 5. Example of an MTD in the Pomeroy Arkose Member along the east side of Oil Bay consisting of disrupted blocks of sandstone enveloped in a disrupted mudstone...............................................7

Figure 6. Field photos showing characteristics of facies F1 .................................................................................. 11

Figure 7. Field photos showing characteristics of facies F2 …………………............................................... 13

Figure 8. Field photos showing characteristics of facies F3 .................................................................................... 15

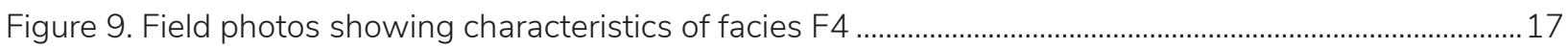

Figure 10. Field photos showing characteristics of facies F5 ..................................................................................19

Figure 11. Field photos showing characteristics of facies F6 ..................................................................................21 
Figure 12. Field photos showing characteristics of facies $\mathrm{F} 7$

Figure 13. Low-altitude, oblique air photo of the lower $25 \mathrm{~m}$ of the section shown in figure $4 \ldots \ldots \ldots \ldots \ldots \ldots \ldots \ldots . . . .24$

Figure 14. Outcrop relations between facies in composite measured section and channel-form

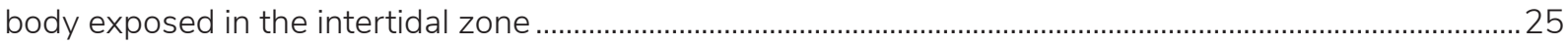

Figure 15. Cartoons showing the interpreted co-genetic origin of facies F2/F3, F5, F6, and F7 ....................26

Figure 16. Block diagram showing the inferred depositional setting of the mass transport deposits exposed near Clam Cove ………………………………………………………………………………........

\section{Tables}

Table 1. Summary of lithofacies characteristics 
Page intentionally left blank 


\title{
DEEPWATER MASS-TRANSPORT COMPLEX IN THE UPPER JURASSIC POMEROY ARKOSE MEMBER, NAKNEK FORMATION, CHINITNA BAY, ALASKA: THE DEPOSITIONAL RECORD OF CO-GENETIC SLUMPS AND DEBRIS FLOWS IN A SLOPE TO PROXIMAL BASIN FLOOR SETTING
}

\author{
David L. LePain ${ }^{1}$, Richard G. Stanley², and Kenneth P. Helmold³
}

\begin{abstract}
We report on a 63.2-m-thick succession of thin-bedded turbidites and concentrated density flow and mass-transport deposits from the uppermost beds of the Upper Jurassic Pomeroy Arkose Member, Naknek Formation, exposed along the north shore of Chinitna Bay, in lower Cook Inlet. Seven lithofacies are recognized, including thinly interbedded sandstone and mudstone (facies F1); massive and horizontally laminated sandstone (facies F2); massive to crudely laminated pebbly sandstone (facies F3); clastsupported, sandy, pebble and cobble conglomerate (facies F4); clast-supported, muddy, pebble and cobble conglomerate (facies F5); matrix-supported, pebbly-cobbly-bouldery conglomerate (facies F6); and chaotically bedded mudstone (facies F7). These facies record deposition from dilute turbidity currents (F1), deposition from concentrated density flows (F2), hyperconcentrated density flows (F3), as gravelly traction carpets at the base of concentrated density flows (F4), clast-rich debris flows (F5), clast-poor debris flows (F6), and slide blocks (F7). All these facies represent points along a continuum of flow conditions and rheologies. Facies relations suggest that F6, F5, F3, and some F2 beds record the progressive evolution of flows derived from mixing along the margins of slide blocks (F7) as the blocks slid down-slope. A common facies stacking pattern recognized in the exposure includes $\mathrm{F} 2 / \mathrm{F} 3 \rightarrow \mathrm{F} 5 \rightarrow \mathrm{F} 6 \rightarrow \mathrm{F} 7$. Where present, $\mathrm{F} 7$ is typically overlain by $\mathrm{F} 2 /$ F3. This motif, combined with the absence of sheared contacts between debris flows and slide blocks, suggests the latter (F7) rode atop clast-poor debris flows (F6) that, in turn, traveled atop clast-rich debris flows (F5). The origin of F2/F3 overlying slide blocks (F7) is unclear, but they may represent the more dilute "tails" derived from extreme mixing along the upper margins of slide blocks and/or debris flows; alternatively, F2/F3 may represent the products of flows unrelated to the mass wasting events responsible for the slide blocks (F7), which is our favored interpretation. The studied succession records a series of relatively small mass-wasting events that originated in a shelf-edge, slope, or proximal basin floor setting. The outcrop-scale stacking pattern suggests a series of retrogressive slope failures, which is consistent with previous studies of the Pomeroy Arkose Member. The source area for these failures was likely the sidewalls of a submarine canyon that incised the nearby slope, or the sidewalls of a leveed channel in the proximal part of a slope apron. The common presence of F4 suggests some degree of channelization of the parent flows.
\end{abstract}

${ }^{1}$ Alaska Division of Geological \& Geophysical Surveys, 3354 College Rd., Fairbanks, Alaska 99709-3707

U.S. Geological Survey, 345 Middlefield Road, MS 969, Menlo Park, CA 94025

${ }^{3}$ Alaska Division of Oil \& Gas, 550 W 7th Ave, Suite 800, Anchorage, Alaska 99501-3560 


\section{INTRODUCTION}

Submarine mass movement is common on inclined areas of the seafloor (Hampton and others, 1996) and, in continental slope settings, is thought to be a major process responsible for sediment transport (Nardin and others, 1979). Mass transport deposits (MTDs) are the depositional record of submarine mass movement and, in some sedimentary basins, comprise more than 50 percent of the stratigraphic record (Weimer and Slatt, 2007). Depending on the facies composition and size of MTDs, they can form effective reservoir seals and, if they include enough sand, can function as reservoirs (Weimer and Slatt, 2007). MTDs encompass a wide spectrum of depositional products, ranging from slide masses characterized by undeformed stratigraphy (except at the margins) to complexly deformed slides to debrites. MTDs can be associated with a wide range of genetically related fluidal flow deposits that result from progressive disaggregation of the original slide masses (Dott, 1963; Nardin and others, 1979; Mulder and Cochonat, 1996). Dramatic examples of large MTDs are shown in many 3D seismic data sets from deepwater settings around the world (see reviews in Posamentier and Walker, 2006; Weimer and Slatt, 2007; Posamentier and Martinsen, 2011; Shipp and others, 2011).

Submarine mass movements vary widely in size from those involving single beds that are centimeters thick and comprising small volumes of sediment (few cubic meters or less) to shelfedge and slope failures involving successions that are hundreds of meters thick and comprise staggeringly large volumes of sediment (Hampton and others, 1996). One of the largest documented slides include the Agulhas slide off South Africa, with a volume of $20,000 \mathrm{~km}^{3}$, and the Storegga slides beyond the northwestern Norwegian shelf, which includes $3,880 \mathrm{~km}^{3}$ of material (Hampton and others, 1996; Maslin and others, 2004). The deposits of the Storegga slide cover an area larger than Scotland (Talling and others, 2012). Although the sizes of these mass movements are impressive, Field and Clark (1979) noted that small slides are common on the slope off California and suggest that small slides also are common on slopes around the world. Such small slides are likely of equal or greater importance overall than are large slides in transporting sediment to deeper marine settings.

The wide spectrum of depositional products associated with submarine mass movements suggests an equally wide range of processes, from translational slides that remain relatively intact, to slides that gradually disaggregate down the transport path and give rise to debris flows and a range of fluidal flows that yield a spectrum of depositional products with diagnostic features (Dott, 1963; Nardin and others, 1979; Lowe, 1982; Hampton and others, 1996; Mulder and Cochonat, 1996; Mulder and Alexander, 2001; Talling and others, 2012). MTDs and genetically related deposits in the stratigraphic record provide important clues about the dominant processes that control sediment transport basinward from outer-shelf and slope settings, and also give detailed information on flow transformations along the transport path. In addition, they provide basin-specific constraints on shelf-slope-basin paleogeography, and the nature of sediment staging areas in outer-shelf and slope settings.

The objectives of this paper are to document lithofacies in a well-exposed succession of stacked MTDs and interbedded high-concentration sediment gravity flow deposits; to use well-preserved sedimentary features to interpret transport and depositional processes, and to explore the genetic linkage between lithofacies and the nature of flow evolution in mass-transport events. To accomplish these objectives, we focus on the upper 63.2 $\mathrm{m}$ of the Pomeroy Arkose Member of the Naknek Formation (Upper Jurassic). The studied succession is well exposed along the north shore of Chinitna Bay in the Iniskin-Tuxedni region of Cook Inlet, south-central Alaska, and consists almost entirely of MTDs and associated high-density sediment gravity flow deposits (figs. 1-3). Two detailed stratigraphic sections were measured through this exposure in May 2010, and additional observations were made in July 2014 and July 2017 


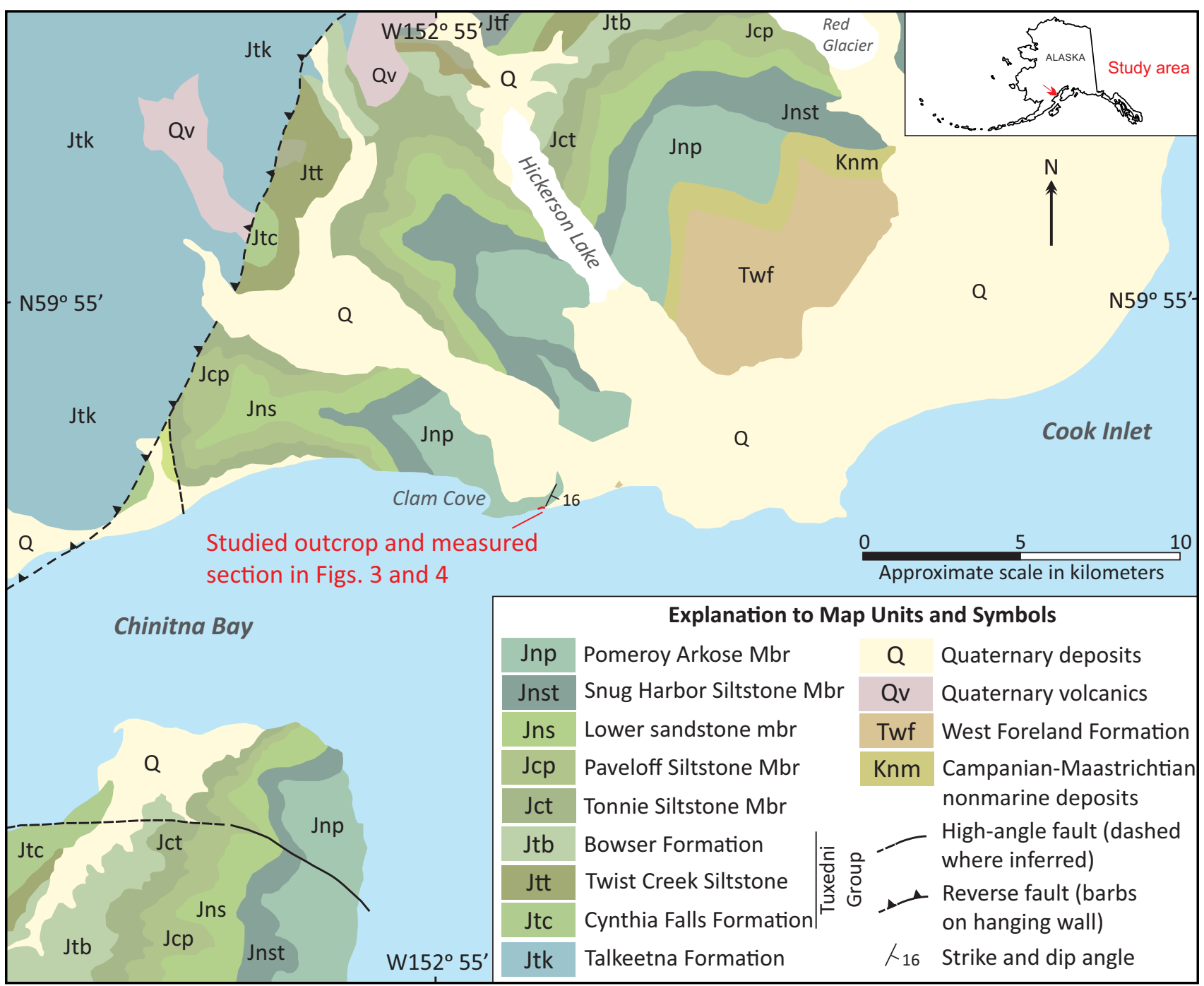

Figure 1. Geologic map of the Chinitna Bay area in lower Cook Inlet, showing the location of the outcrop addressed in this report. Modified from Wilson and others (2012).

(fig. 4). The measured sections are separated by a minor fault zone with about $8 \mathrm{~m}$ of vertical displacement (fig. 3A and 3B). These sections form the database for the facies analysis presented in this paper. Process-response interpretations are provided for each facies, and facies stacking patterns are used to place the succession in a depositional systems framework. Finally, the facies characteristics, contact relations, and stacking patterns are used to explore flow evolution during mass-wasting events.

While this report is based on a single exposure that could be viewed as limited, the outcrop addressed is significant as it includes a well-exposed, repetitive series of MTDs and interbedded sediment gravity-flow deposits that we interpret as co-genetic. The succession appears to be unique among exposures of the Pomeroy Arkose; we are not aware of another accessible outcrop in the area that includes a thick succession of stacked MTDs and associated deposits. The exposure is relatively unweathered and free of colluvium due to the frequent and vigorous cleaning action of breaking waves associated with spring tides that coincide with strong southeasterly winds from the north Pacific. These conditions permit recognition of subtle depositional features at the bed scale that provide important clues for understanding sediment transport and depositional processes associated with mass wasting events. 


\section{GEOLOGIC SETTING}

The Upper Jurassic Naknek Formation is a thick succession of marine conglomerate, sandstone, and siltstone deposited in a forearc basin associated with the Talkeetna volcanic arc (Trop and Ridgway, 2007; LePain and others, 2013;

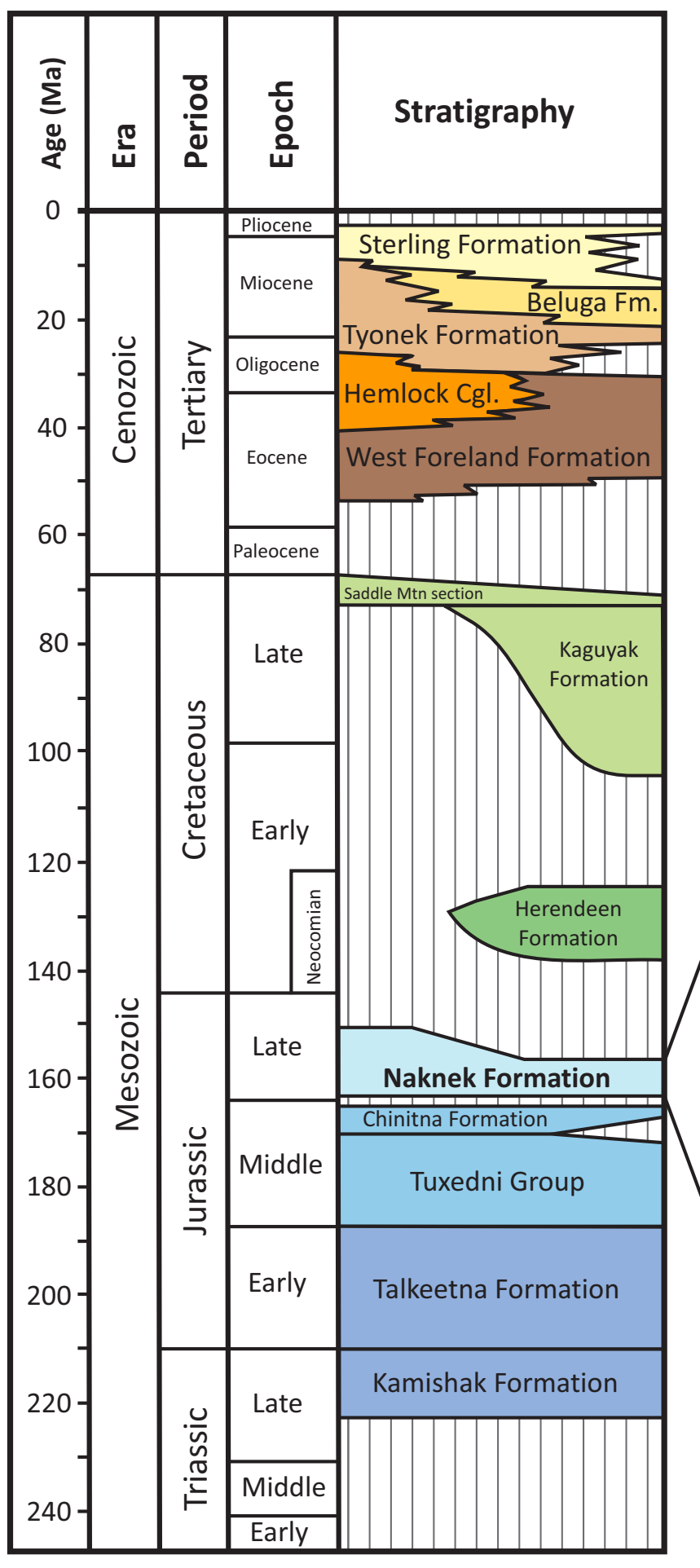

figs. 1 and 2). In the study area, the unit is a synorogenic, largely conformable, deepening-upward succession comprising first cycle volcanic and plutonic detritus shed from a rapidly rising and exhuming magmatic arc (Helmold and others, 2013; Wartes and others, 2013; Helmold and others, 2018). The basal units - the Chisik Conglomerate Member and lower sandstone member - are laterally equivalent and correlative (Detterman and Hartsock, 1966), and record deposition in fan delta and marine shelf settings, respectively (Wartes and others, 2013, 2015). These units are overlain by the Snug Harbor Siltstone, which is interpreted as outer shelf to slope deposits (Wartes and others, 2013; Herriott and others, 2017). In the Iniskin-Tuxedni region, the Pomeroy Arkose Member is the youngest member of the Naknek Formation; is more than $1,000 \mathrm{~m}(3,300$ $\mathrm{ft}$ ) thick; and consists of arkosic sandstone, pebble conglomerate, and siltstone (Detterman and Hartsock, 1966). Throughout much of its thickness, the unit comprises a monotonous succession of medium to very thick, tabular-bedded sandstone with minor thinner interbeds of siltstone. Sandstone channel fills and conglomerate are present locally, where they form conspicuous lithotypes. A meager fauna suggests the unit is late Oxfordian to early Kimmeridgian (Detterman and Hartsock, 1966, p. 55). Detterman and Westermann (1992) subsequently

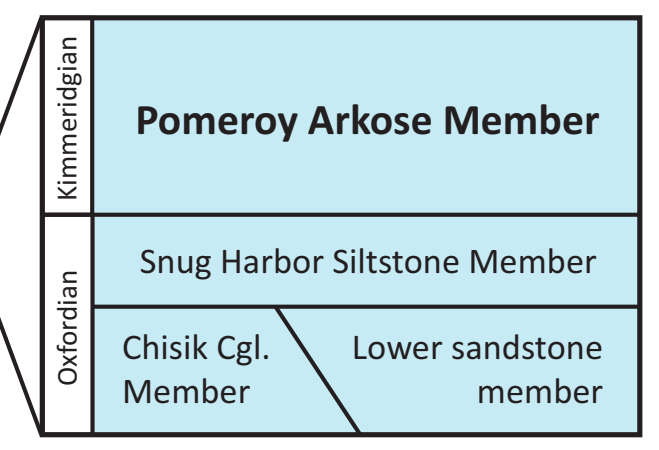

Figure 2. Generalized stratigraphic column for Cook Inlet basin. The outcrop addressed in this report includes slope to base-of-slope deposits at the top of the Pomeroy Arkose Member. Modified from Swenson (2003) and unpublished industry data; additional information from Plafker and others (1989) and Nokleberg and others (1994). 

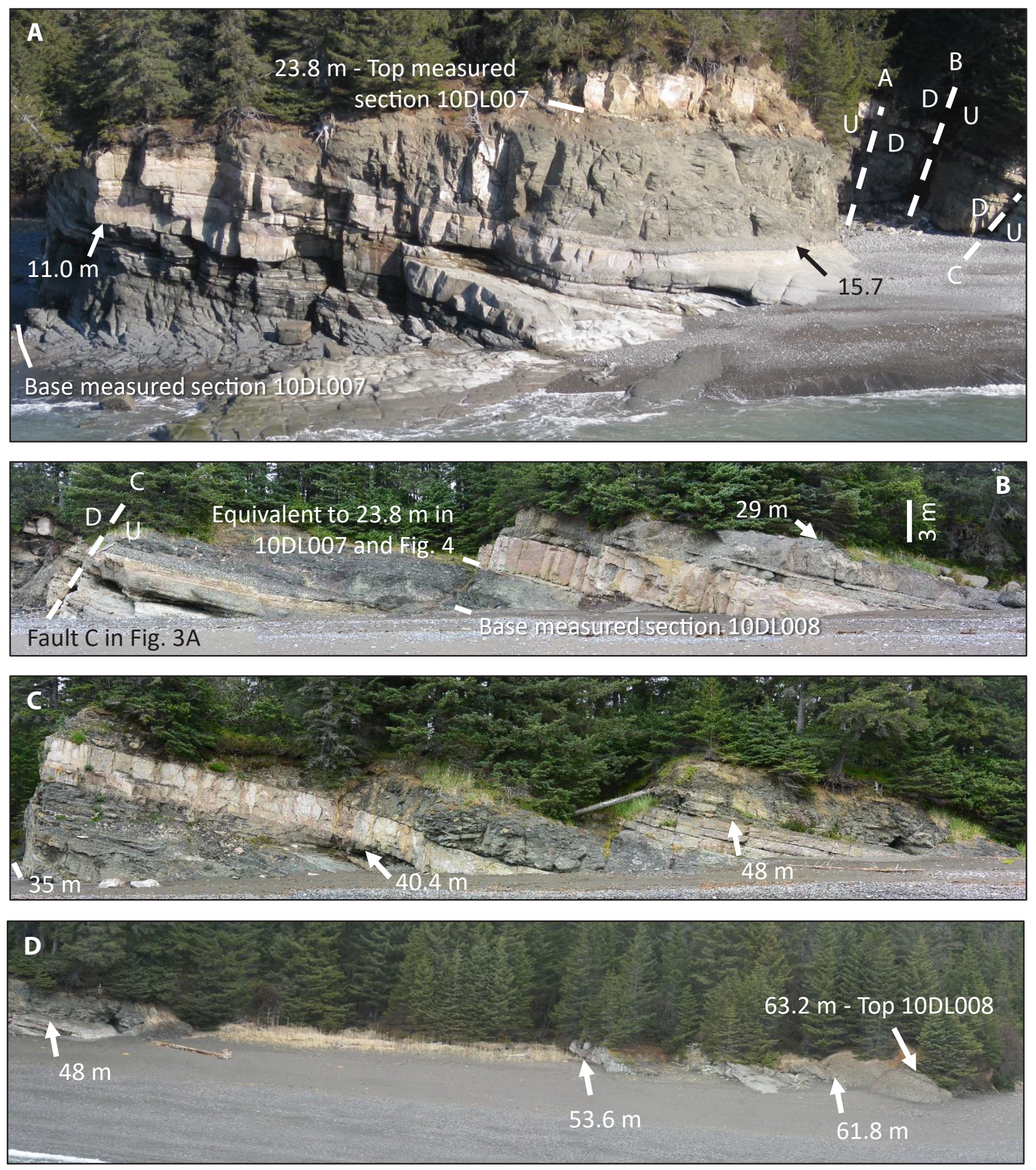

Figure 3. Low-altitude, oblique aerial photographs showing the upper $63.2 \mathrm{~m}$ of the Pomeroy Arkose Member at its type section along the north shore of Chinitna Bay. See figure 1 for location. The view is toward the north in all photographs. A. Photograph showing measured section 10DL007. Note the fault zone visible near the east side (right) of the image. This zone separates measured sections 10DL007 and 10DL008. Beds near the top of 10DL007 and base of 10DL008 were correlated across the fault zone with high confidence, allowing the two sections to be stitched together to form the single, composite measured section shown in figure 4. B-D. Photographs showing measured section 10DL008. Note the fault visible near the west (left) edge of image in B is the same fault that is visible at the eastern edge of A. A minor gap separates the eastern edge of B. from the western edge of $C$. The images in $C$ and $D$ overlap. The outcrop ends near the east side of $\mathbf{D}$. The next outcrop to the east, along the shoreline, is the Cenozoic West Foreland Formation. The latitude and longitude of the base of section 10DL007: is N59.877751, W152.924387. The latitude and longitude of the base of section 10DL008 is N59.877901, W152.923031. Datum is WGS84. 


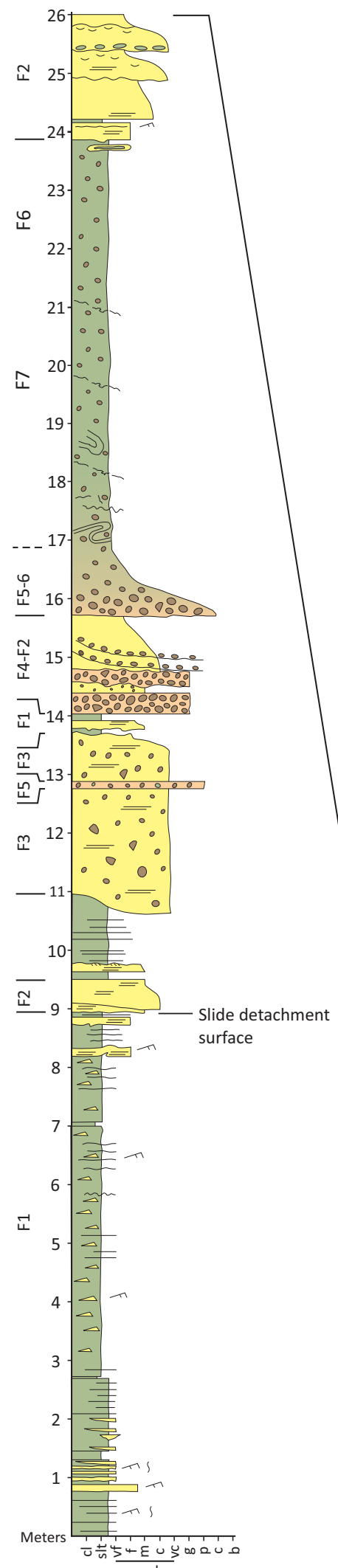

sand

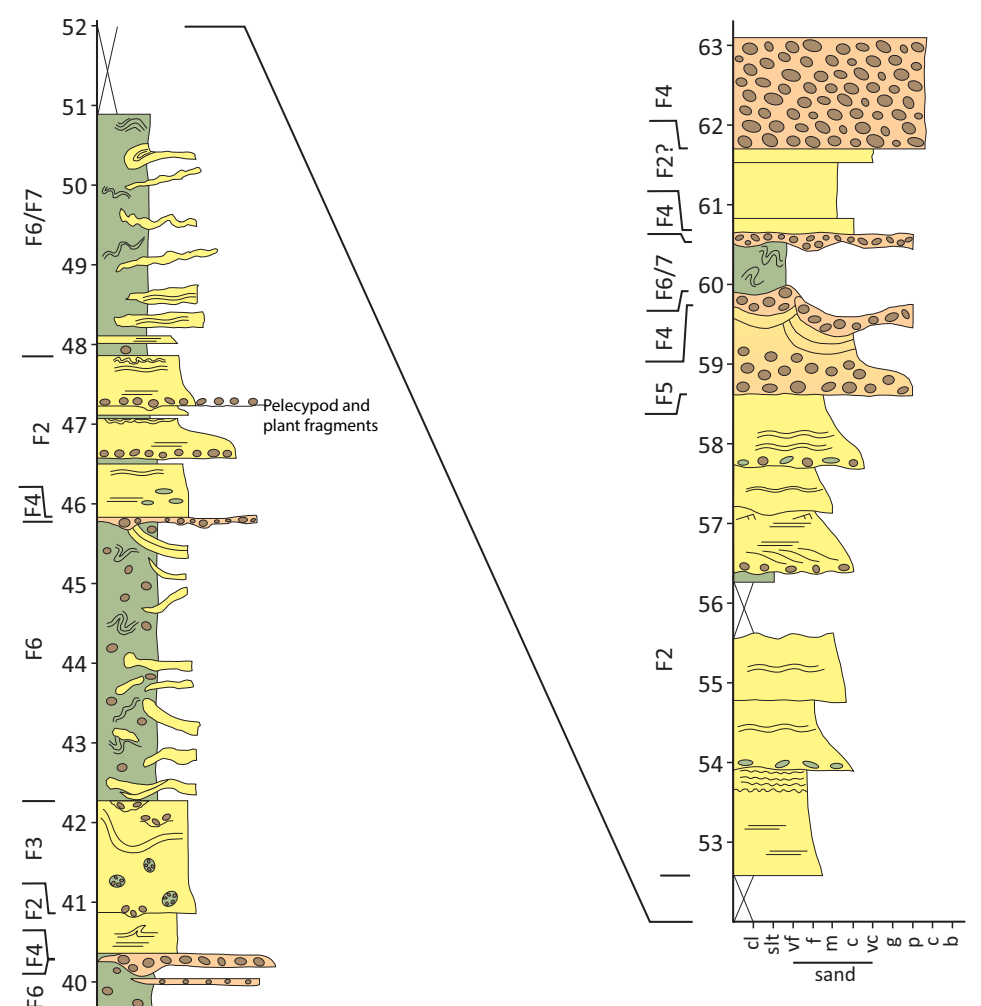

(o 40 \%....

=

무 $3 9 \longdiv { \overline { \frac { 1 } { \overline { T } } } }$

- 0

ᄂ $38 \frac{0}{-\frac{1}{01}}$

7

ㄴ. ㄴ.

บ $36-2=0$

35

$35-20$

$34-\stackrel{0}{-1}$

$- 3 4 \longdiv { 0 }$

ํㅜㄴ $33-0^{\circ}$

$-32-0000000000$

\begin{tabular}{ll} 
Lithologies & KEY \\
\hline Sandstone & Mudstone \\
\hline $0_{0}$ Conglomerate & Pebbly sandstone \\
\hline & Conglomerate grading \\
\hline
\end{tabular}

Sedimentary Stuctures

- Horizontal lamination $\Rightarrow$ Armored mudball

$\approx$ Wavy lamination

Mudstone ripup clast

$\approx \approx$ Convolute lamination

2 Convolute bedding

- Extrabasinal clasts

प $29-$ a

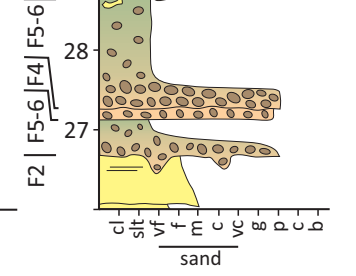

Sandstone raft

Current ripple

cross-lamination

$\smile$ Dish structures

Sigmoid

$\sim \sim$ Pelecypod valves

Pebble-lined

scour

) Bioturbation

$\triangle$ Starved current $\quad$ Gutter cast ripples

Figure 4. Composite measured stratigraphic section through the upper $63.2 \mathrm{~m}$ of the Pomeroy Arkose Member, Naknek Formation. Facies codes (F1-F7) are shown to the left of the column. See text for discussion of facies. The grain size scale at the base of the section is the Wentworth scale as shown in Folk (1980). 
showed the entire Pomeroy Arkose Member as Kimmeridgian (their fig. 4.14). Ravn (personal communication to LePain, 2011) analyzed palynomorphs and dinoflagellate cysts in several mudstone samples collected by the authors from the outcrop addressed in this report, and concluded the strata are of Late Jurassic age. The Pomeroy was deposited below maximum storm wave-base in slope to baseof-slope settings, and much of the unit was deposited in a slope apron depositional system (Herriott and others, 2017). MTDs are relatively uncommon but widely distributed in the Pomeroy Arkose, and are locally conspicuous on inaccessible, near-vertical mountainsides and in a few beach exposures (fig. 5).

Herriott and others (2017) documented a series of large, canyon-scale sediment routing conduits associated with the deepwater Snug Harbor Siltstone and Pomeroy Arkose Members in outcrop between Chisik Island and the south end of the Iniskin Peninsula (figs. 1 and 2). Basal incisions of these features, which are kilometers wide and hundreds of meters deep, locally cut through the entire thickness of the Snug Harbor Siltstone and are filled with sand-rich facies of the uppermost Snug Harbor and lower part of the Pomeroy Arkose. These seismic-scale stratigraphic relations, along with shelfal facies in the lower sandstone member, demonstrate the existence of a depositional shelf-slope-basin bathymetric profile in this part of forearc basin by the Late Jurassic (Oxfordian-Kimmeridgian).

The exposure of the Pomeroy Arkose Member addressed in this report is located on the north shore of Chinitna Bay, approximately $1.6 \mathrm{~km}$ east of Clam Cove, and comprises the uppermost beds of the type section for the member (figs. 1 and 2; Detterman and Hartsock, 1966). The unit dips 10-16 degrees toward the east and is unconformably overlain by the Paleogene (Eocene) nonmarine West Foreland Formation.

The reader is referred to Herriott and others (2017) and Wartes and others $(2013,2015)$ for additional information on the Naknek Formation in the Iniskin-Tuxedni region, and to Trop and others (2005) for a discussion of the formation in the Talkeetna Mountains northeast of Cook Inlet.

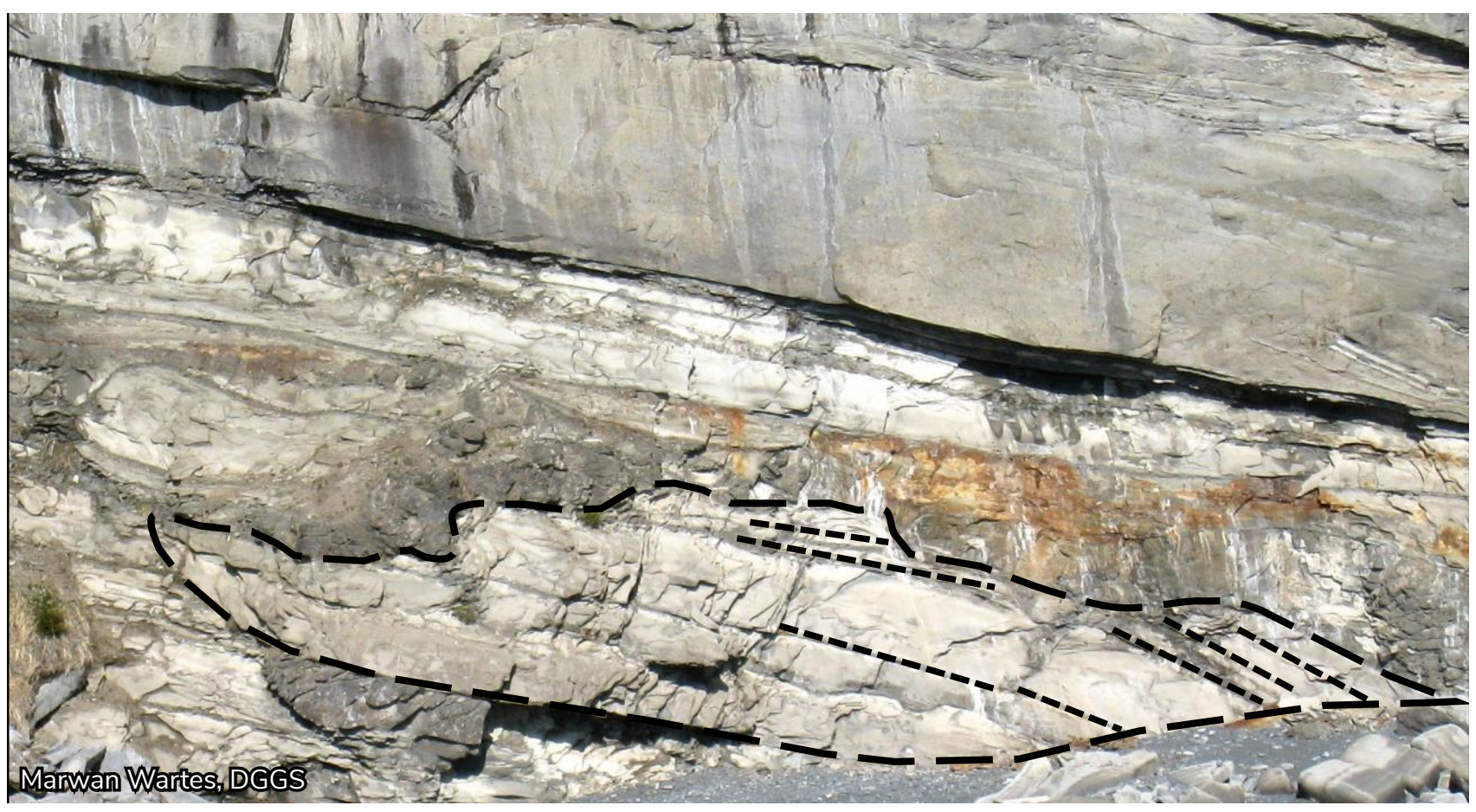

Figure 5. Example of an MTD in the Pomeroy Arkose Member along the east side of Oil Bay consisting of disrupted blocks of sandstone enveloped in a disrupted mudstone. 


\section{METHODS}

The succession addressed in this paper is located in a roadless region accessible only by boat or aircraft (helicopter or float plane). We measured two detailed stratigraphic sections using a jacob staff equipped with a clinometer. Section 10DL007 is located west of a minor fault zone and documents the lower $23.2 \mathrm{~m}$ of the succession (fig. 3A); section 10DL008 is located east of the fault zone and includes the upper $49.8 \mathrm{~m}$ (figs. 3B-D). The combined thickness of these two sections is $73 \mathrm{~m}$. Similarities in stratigraphy, bed-scale features, and facies near the top of 10DL007 and the base of 10DL008 allow the two sections to be stitched together with high confidence and are shown herein as a single measured section covering a stratigraphic thickness of 63.2 $\mathrm{m}$ (fig. 4). In this report, we document bed thickness, bedding geometry, nature of bed contacts, grain size, sedimentary structures, ichnofabric, and fossil content (trace and body fossils). We use Taylor and Goldring's (1993) bioturbation index to describe the degree of bioturbation (a bioturbation index of 0 corresponds to no bioturbation and an index of 6 corresponds to complete sediment reworking by burrowing organisms and repeated overprinting). We abbreviate bioturbation index as BI (e.g. BI 0, BI 1, BI 2 and so on). These characteristics form the basis for recognizing seven lithofacies (table 1). Lithofacies characteristics, contact relations, and stacking patterns are used to identify genetically related sedimentation units. High-resolution, oblique digital photographs were taken at low elevation from a helicopter to document lateral variations in bedding thickness and changes in the geometry of surfaces bounding individual beds and genetically related bedsets.

In the facies analysis that follows, we use Mulder and Alexander's (2001) classification of subaqueous sedimentary density flows, which is based on sediment composition (cohesive or non-cohesive), inferred sediment concentration, and inferred particle support mechanism(s). We follow Posamentier and Martinsen's (2011) terminology and restrict our use of the term mass transport deposit (MTD) to sediment masses that were transported to the depositional site en masse in which sediment particles were not free to move appreciably relative to one another. By this definition, only slide masses and debrites are included in MTDs despite the fact that slides and debris flows commonly transform during movement to a variety of fluidal density flows (Dott, 1963; Lowe, 1979; Nardin and others, 1979; Mulder and Alexander, 2001; Talling and others, 2012).

\section{FACIES ANALYSIS}

We recognize seven lithofacies (designated F1 through F7) that record a spectrum of flow rheologies and depositional processes-from "classic" turbidites, in which sediment concentrations were low and fluid turbulence was the dominant support mechanism, to coherent but internally deformed slide masses in which bedding is still recognizable. Facies characteristics are summarized in table 1 .

\section{Facies 1 (F1): Thinly Interbedded Sandstone and Mudstone Description}

F1 consists of medium gray to olive-green mudstone and thinly interbedded medium- to light-gray, moderately- to well-sorted, very finegrained sandstone (fig. 6A); a few beds of moderately sorted, medium- to coarse-grained sandstone are also present. Mudstone is typically massive and characterized by irregular chippy to blocking parting (figs. 6A-F). Most sandstone beds range in thickness from a few millimeters to $15 \mathrm{~cm}$; sandstone beds thicker than $15 \mathrm{~cm}$ are present but are less abundant and consist of medium-to coarsegrained sand. Sandstone beds mostly consist of Bouma Tbc and Tc sequences (figs. 6B and 6C), but the Ta division is present locally. Sandstone lenses comprising starved current ripples are common (fig. 6D). Sand-filled scours resembling gutter casts are present in mudstone, but are not abundant. A few beds include chaotic-appearing folds (fig. 6E). Most sandstone beds are unbioturbated 


\begin{tabular}{|c|c|c|c|c|}
\hline 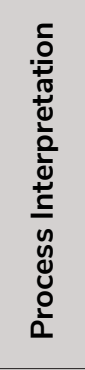 & 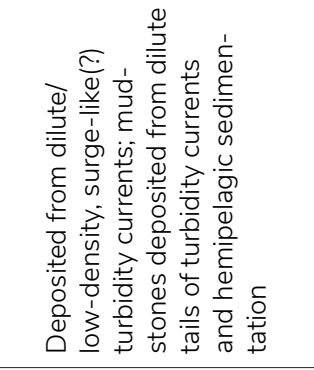 & 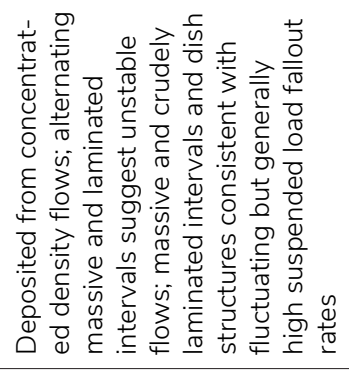 & 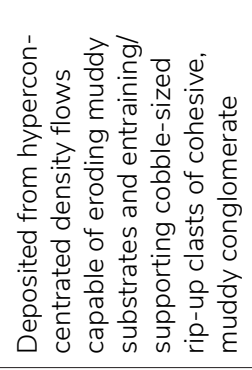 & 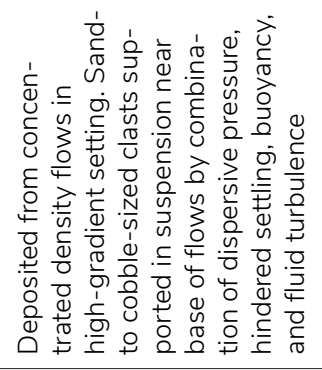 \\
\hline 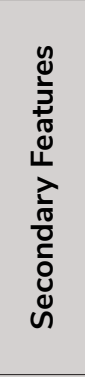 & 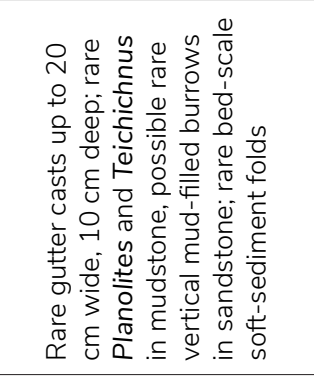 & 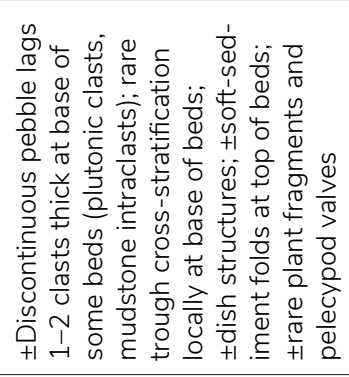 & 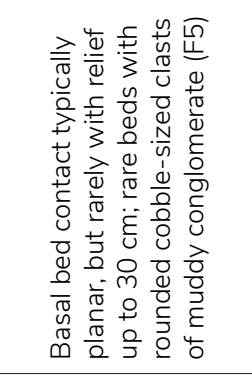 & 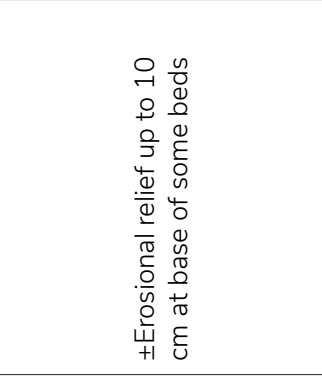 \\
\hline 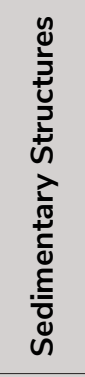 & 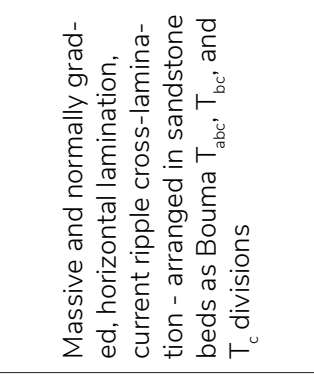 & 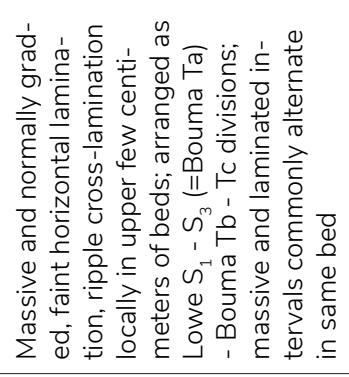 & 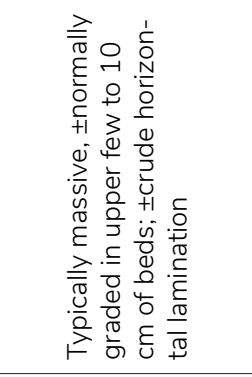 & 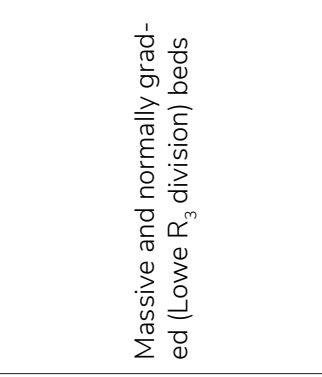 \\
\hline 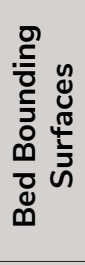 & 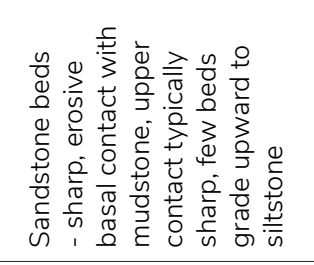 & 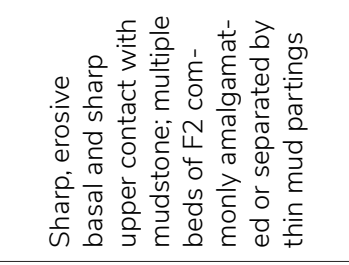 & 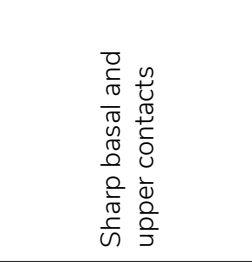 & 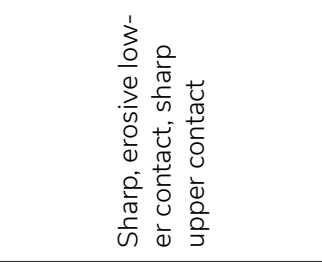 \\
\hline 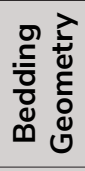 & 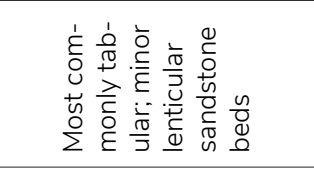 & $\begin{array}{l}\frac{\bar{\pi}}{\frac{10}{2}} \\
\frac{0}{10} \\
\frac{0}{\hbar}\end{array}$ & $\begin{array}{l}\frac{\bar{\pi}}{\overline{5}} \\
\frac{0}{\sigma} \\
\vdash\end{array}$ & 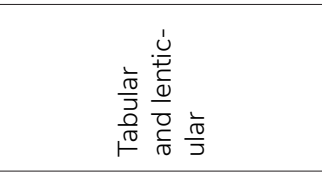 \\
\hline 总 & 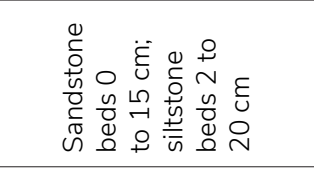 & 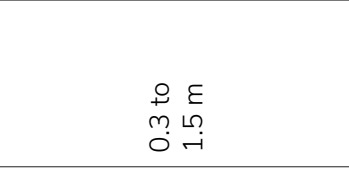 & 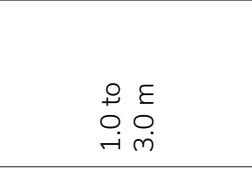 & 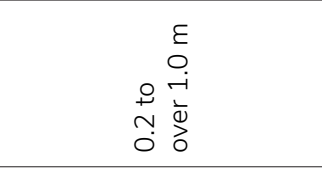 \\
\hline 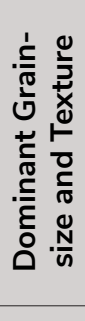 & 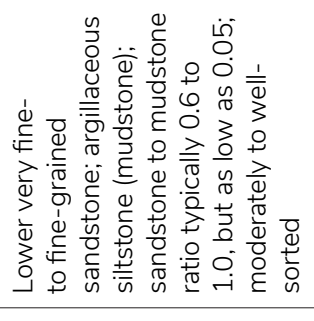 & 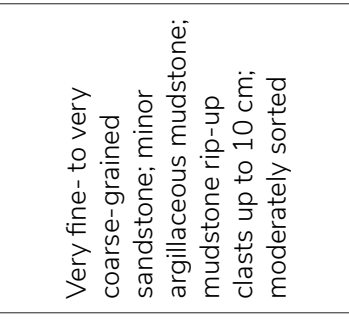 & 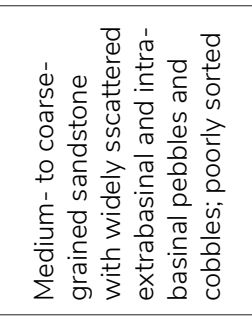 & 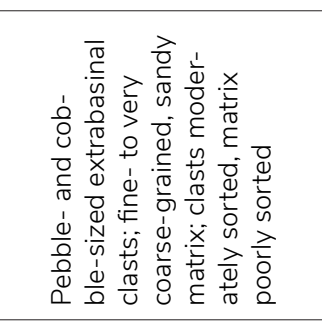 \\
\hline $\begin{array}{l}\tilde{y} \\
\frac{\tilde{u}}{\tilde{u}} \\
\tilde{L}\end{array}$ & 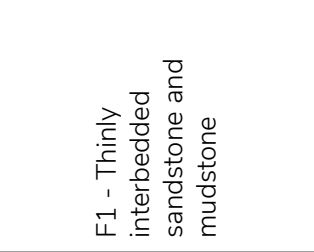 & 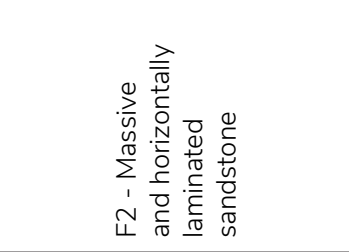 & 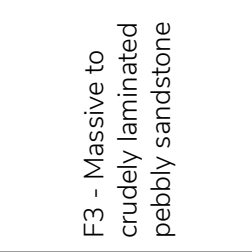 & 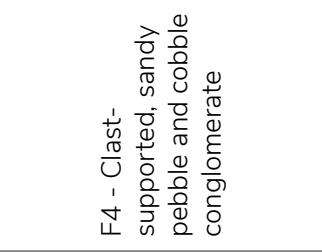 \\
\hline
\end{tabular}




\begin{tabular}{|c|c|c|c|}
\hline 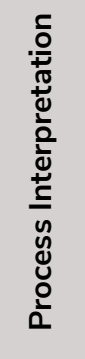 & 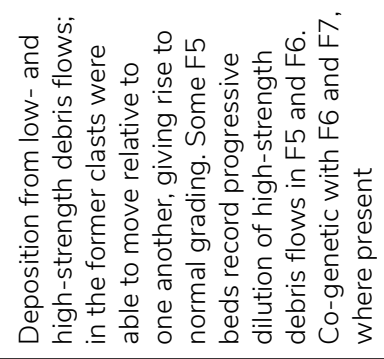 & 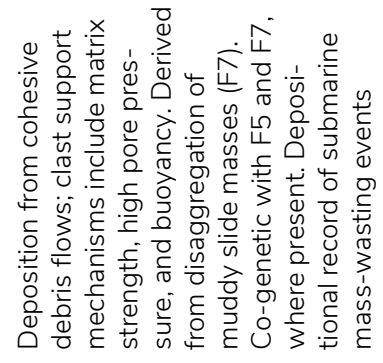 & 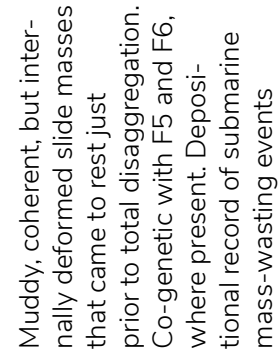 \\
\hline 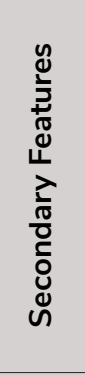 & 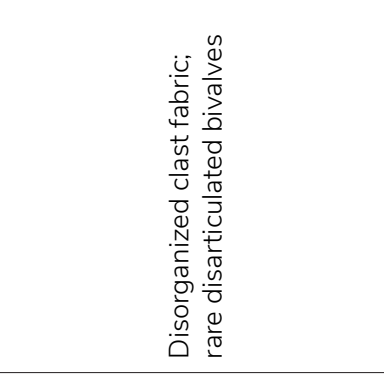 & 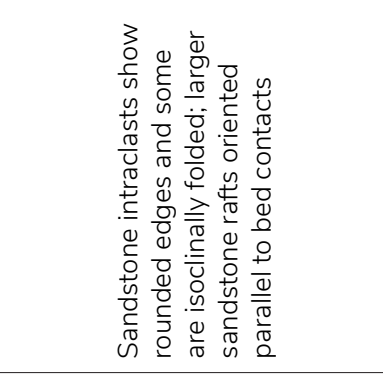 & 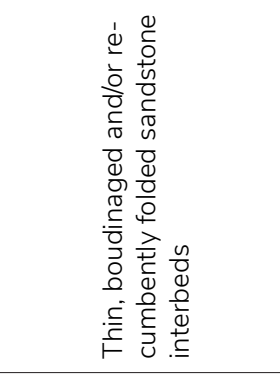 \\
\hline 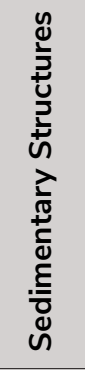 & 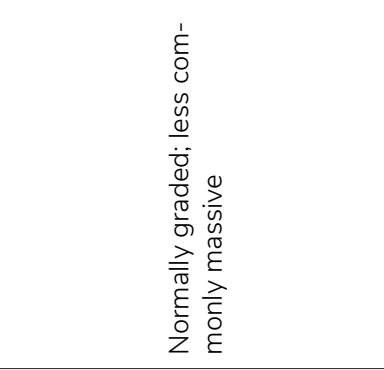 & 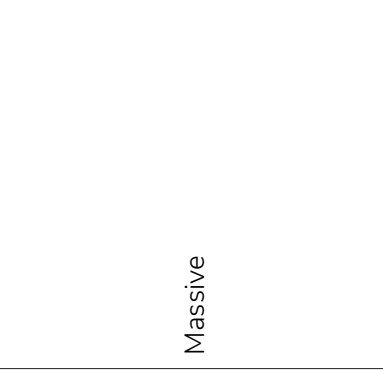 & 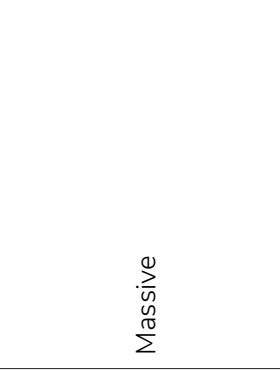 \\
\hline 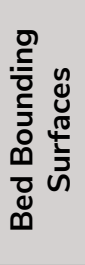 & 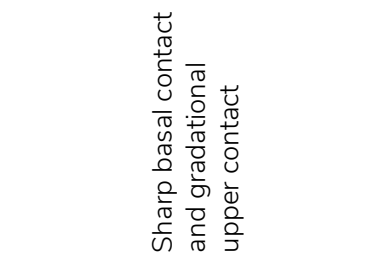 & 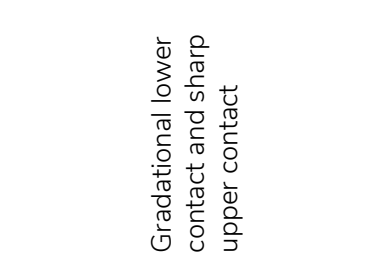 & 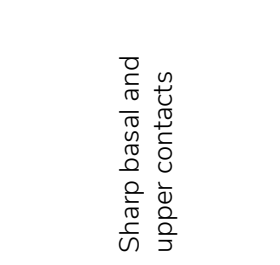 \\
\hline 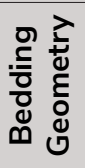 & $\begin{array}{l}\frac{\frac{\pi}{\pi}}{\overline{2}} \\
\frac{0}{10} \\
\frac{0}{\hbar}\end{array}$ & 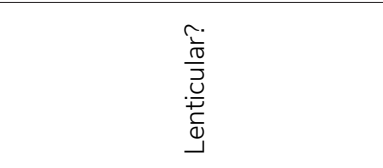 & 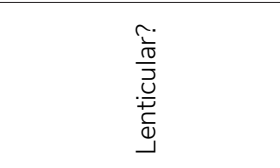 \\
\hline סु & $\begin{array}{ll}\circ & \varepsilon \\
\stackrel{1}{-1} & 0 \\
0 & -\end{array}$ & 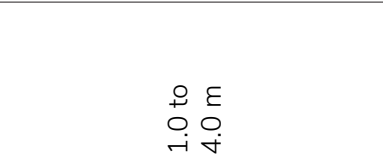 & $\begin{array}{l}\tilde{O} \\
\dot{m} \\
\dot{0} \\
\stackrel{0}{0} \\
\stackrel{N}{j}\end{array}$ \\
\hline 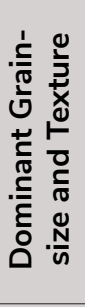 & 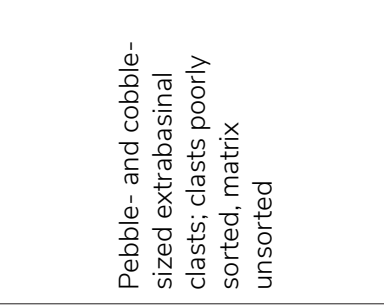 & 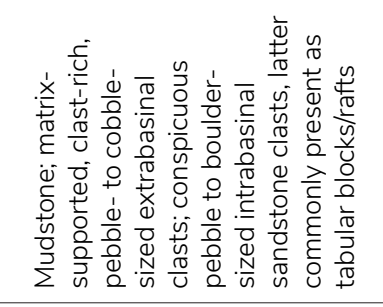 & 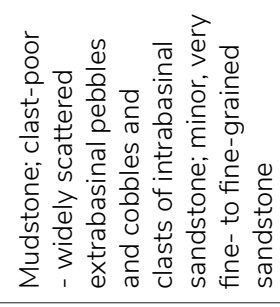 \\
\hline $\begin{array}{l}\frac{\tilde{y}}{\tilde{u}} \\
\tilde{\leftarrow} \\
\tilde{L}\end{array}$ & 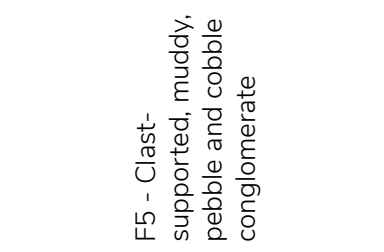 & 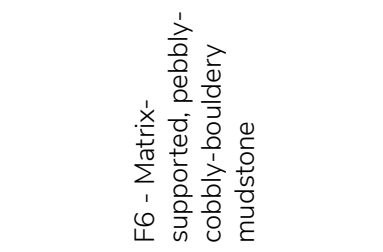 & 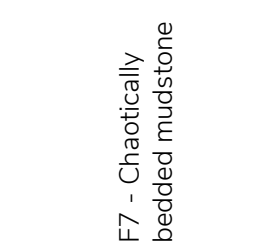 \\
\hline
\end{tabular}



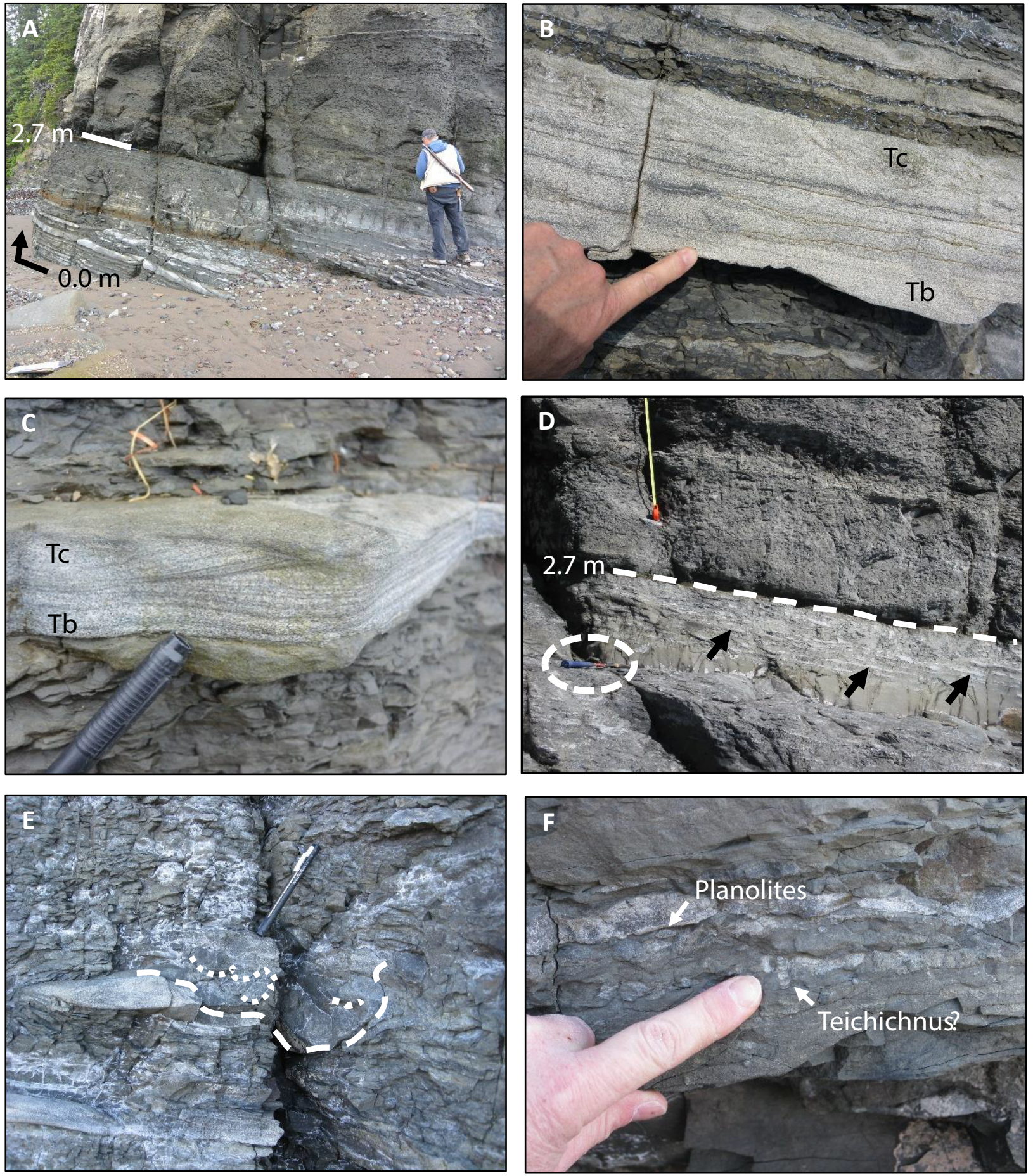

Figure 6. Field photos showing characteristics of facies F1. A. Sandstone beds displaying partial Bouma sequences, including Tb, Tbc, and Tc interbedded with mudstones. Mudstones represent the dilute tails of the turbidity currents responsible for transporting sand-sized detritus. B. Bouma Tbc sandstone bed at $1.7 \mathrm{~m}$. Note the erosional relief on the base of the bed to the right of the geologist's finger. $\mathbf{C}$. Bouma Tbc sandstone bed at approximately $1.7 \mathrm{~m}$. Note the erosional relief on the underside of the sandstone bed near the tip of the gray eraser. Visible part of eraser is $6 \mathrm{~cm}$ long. D. F1 from 2.0 to $4.0 \mathrm{~m}$ showing an abrupt decrease in grain size from coarse siltstone to siltstone at $2.7 \mathrm{~m}$. This grain size decrease also corresponds to an abrupt decrease in sandstone. E. Soft-sediment deformation in sandstone bed in the lower $2 \mathrm{~m}$ of measured section. The deformation mechanism is unknown, but deformation is likely due to one of the following: gravity sliding down slope, sand bed foundering in a muddy substrate, or frictional drag at the base of turbidity current. F. Thin sandstone beds in green-gray sandy siltstone. Both lithologies are sparsely to moderately bioturbated (BI 1 for sandstones and BI 4 or higher in mudstones). Trace fossils include compacted Planolites and possible Teichichnus. 
(BI 0), but burrows are present locally (BI 1) and include Planolites and possible Teichichnus (fig. 6F). Few discrete trace fossils have been recognized in mudstones of F1, which usually have a subtle but pervasive, mottled appearance (BI 4 or higher?).

\section{Interpretation}

F1 resembles the deposits of surge-like turbidity currents (low sediment concentration; Mulder and Alexander, 2001; Talling and others, 2012). The absence of a basal massive Ta division in most beds suggests deposition from suspension (sand-sized particles supported in flow by fluid turbulence) and subsequent transport to the final depositional site by tractive processes. Sandfilled scours resembling gutter casts resulted from turbulent eddies that scoured the muddy substrate (Myrow, 1992). The apparent absence of primary physical sedimentary structures in mudstone suggests suspension sedimentation from plumes of fine-grained sediment and, possibly, from the dilute tails of turbidity currents. The faintly visible mottled appearance of mudstones suggests thorough mixing by burrowing organisms. Most sandstones are unbioturbated, but a few contain simple traces suggesting they were created by a transported fauna (doomed pioneers of Follmi and Grimm, 1990; MacEachern and others, 2007). Sandstones in F1 lack climbing ripple cross-lamination and mudstone rip-up clasts, suggesting deposition from relatively low-volume, non-erosive flows, yet the rare presence of gutter cast-like features suggests some flows were erosive.

\section{Facies 2 (F2): Massive and Horizontally Laminated Sandstone Description}

F2 consists of light tan weathering, moderately- to well-sorted, very fine- to very coarsegrained sandstone and minor interbedded graygreen mudstone (fig. 7A). Sandstone beds are tabular and range from 0.3 to $1.5 \mathrm{~m}$ thick, are commonly amalgamated, and often include thin, discontinuous basal lags of extrabasinal granules and pebbles, and mudstone ripup clasts (figs. $7 \mathrm{~B}$ and $7 \mathrm{C}$ ). Some beds include discontinuous pebble lags that can be traced laterally and downward to underlying pebble conglomerate beds of F4 (figs. $7 \mathrm{D}$ and 9E). F2 includes beds that are massive throughout (fig. 7E), normally graded (fig. 7F), normally graded and overlain by horizontal laminations (fig. 7G), as well as massive and horizontally laminated intervals interspersed throughout their thickness. Cross-bedding and small-scale ripple cross-lamination are present locally but are not common, and the latter structure is limited to the upper few centimeters of beds in which it occurs. The underside of some sandstone beds includes linear sole marks and load structures (fig. $7 \mathrm{G}$, above and to right of hammer head). Isolated,

Figure 7, following page. Field photos showing characteristics of facies F2. A. Sandstone beds of F2 from approximately 45.9 $\mathrm{m}$ to $47.9 \mathrm{~m}$ showing tabular geometry and typical thickness range. B. Sandstone bed from $47.2 \mathrm{~m}$ to $47.9 \mathrm{~m}$. Note the massive texture near the geologist's finger and amalgamated scour surfaces overlain by normally graded sandstone (red triangles). Note also the fluid escape feature at the top of the bed (black arrow). C. Sandstone bed of F2 from $25.4 \mathrm{~m}$ to $25.8 \mathrm{~m}$ with prominent mudclasts at base of bed and well-developed dish structures in upper half of bed (black arrows). Dashed black lines show lower and upper bed contacts. Visible part of hammer is $18 \mathrm{~cm}$ long. D. Sandstone bed of F2 from $14.8 \mathrm{~m}$ to $15.7 \mathrm{~m}$ showing isolated lenses of pebble conglomerate and discontinuous pebble stringers that extend from the interior of sandstone bed downward into the underlying conglomerate bed (F4). These stringers define down-stream accretion surfaces, which are rare in F2. Hammer is $42 \mathrm{~cm}$ long. E. Beds of F2 at the base of a gully fill feature exposed in the intertidal zone immediately south of measured section 10DL007. Gully is incised into interbedded mudstone and sandstone of F1 (see fig. 14). Hammer (dashed black oval) is $42 \mathrm{~cm}$ long and field notebook is $19 \mathrm{~cm}$ long. F. Graded bed of F2 from $46.6 \mathrm{~m}$ to approximately $47.1 \mathrm{~m}$. Note stacked graded intervals, which are interpreted as the product of a single event in which the flow was unsteady. This interval is shown in figure 4 as a single fining-upward bed for ease of drafting. G. Sandstone bed of F2 showing load cast with superimposed linear grooves and prominent sub-centimeter- to centimeter-scale lamination. Note some laminae appear normally graded based on weathering color - grading from light beige sand to gray mud-rich sand. Numbers on pink survey flags show meterage in measured section 10DL008; base of bed is at $57.01 \mathrm{~m}$ in figure 4 . The rock hammer is $42 \mathrm{~cm}$ long. H. Poorly preserved plant fragments (black arrows) and disarticulated pelecypod valve (white arrow) at $47.0 \mathrm{~m}$. 

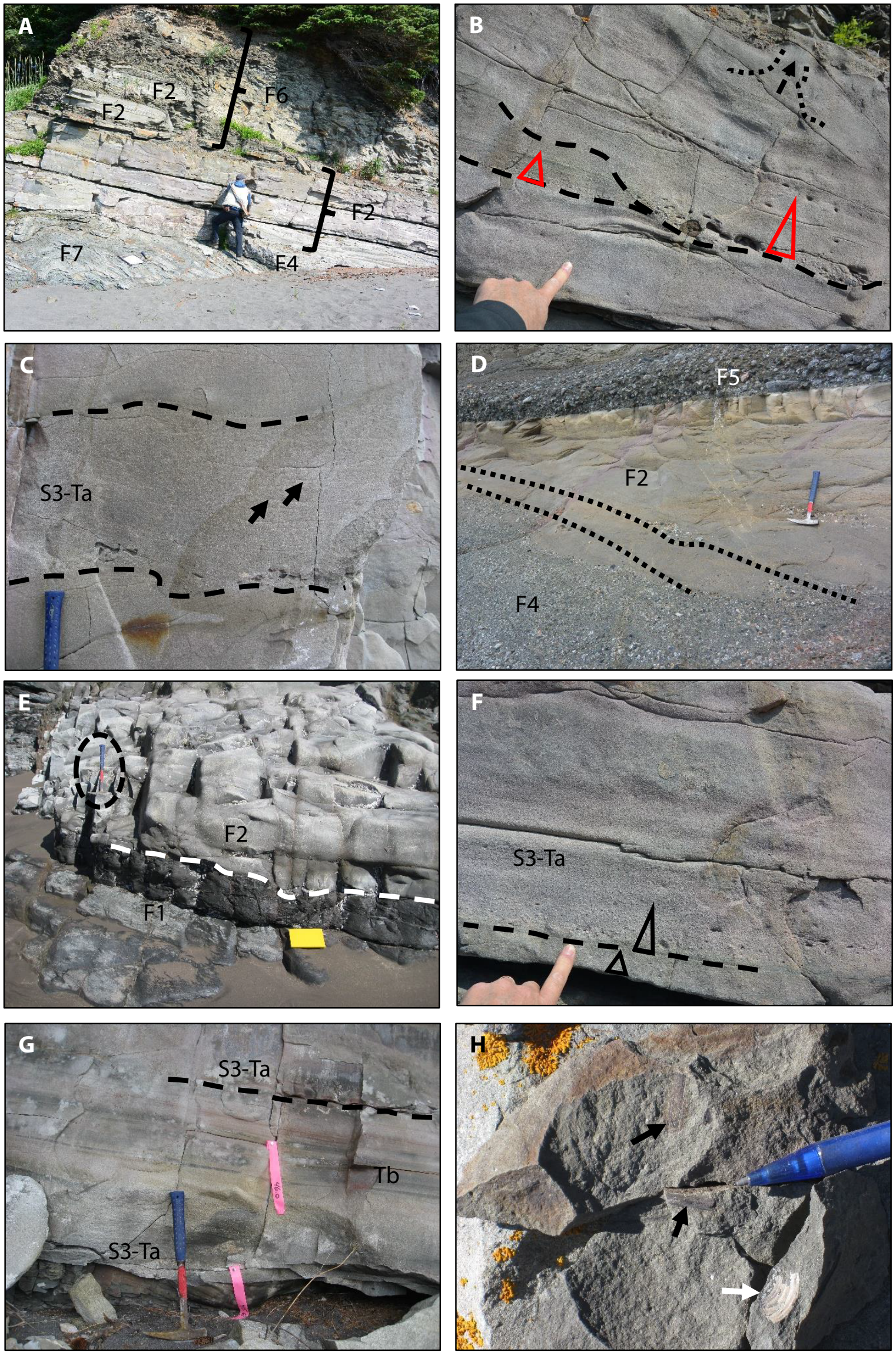
small pockets of anomalously coarse sediment are present in mudstone immediately beneath some sandstone beds. Pebble-sized clasts of granitic and dioritic plutonic and mafic volcanic rocks are widely dispersed in some beds. Dish structures and fluid escape pipes are common in massive sandstones (figs. 7B and C). Disharmonic soft-sediment folds characterize the upper 5 to $20 \mathrm{~cm}$ of many beds. Mudstone is typically absent but, where present, is structureless and limited to beds less than $20 \mathrm{~cm}$ thick. Fossils are rare and include small plant and pelecypod fragments (fig. $7 \mathrm{H}$ ). Bioturbation has not been recognized in facies F2 (BI 0 ).

\section{Interpretation}

F2 was deposited from concentrated (high sediment concentration) density flows. Grainto-grain collisions, sediment buoyancy, and fluid turbulence all contributed to supporting sand-sized particles in the body of these flows (Lowe, 1982; Mulder and Alexander, 2001; Talling and others, 2012). Mudstone rip-up clasts indicate turbulent scour over muddy substrates up-flow from the depositional site. Massive beds and layers within beds record high sediment fall-out rates with little or no subsequent traction transport. Horizontally laminated intervals record reduced sediment fallout rates such that tractive processes were able to move sand as a traction carpet at the base of the flow (Lowe, 1988). Beds with alternating massive and laminated intervals suggest unsteady flows, with conditions varying from high sediment fallout rates and no traction to low fallout rates with tractive transport. Beds with pebble conglomerate lags resulted from flows that transported gravel in discontinuous traction carpets at their base. Pebbles widely dispersed throughout F2 beds are consistent with transport in suspension in concentrated density flows with high sediment fallout rates. Dewatering features (dish structures and fluid escape pipes) indicate rapid deposition from suspension without subsequent traction transport (Lowe and Lopiccolo, 1974). Isolated pockets of anomalously coarse-grained sediment in mudstones immediately below some beds of F2 suggest the contacts at the base represent bypass surfaces, along which a considerable volume of coarse-grained sediment bypassed the depositional site and was transported farther basinward.

\section{Facies 3 (F3): Massive to Crudely Laminated Pebbly Sandstone Description}

F3 consists of medium- to coarse-grained, poorly to moderately sorted sandstone. Pebble- and cobble-sized extrabasinal clasts (mafic and intermediate volcanic and plutonic lithologies) are widely scattered throughout beds and appear to float in a sandy matrix (figs. $8 \mathrm{~A}$ and $8 \mathrm{~B}$ ); scattered spheroidal- to ellipsoidal-shaped mudstone clasts and clasts of muddy, clast-supported pebble conglomerate are present locally (figs. 8A and 8C). Sandstone beds range from 1 to $3 \mathrm{~m}$ thick, are tabular, and some display up to $40 \mathrm{~cm}$ of erosional relief on their base (fig. 8A). Most beds appear internally massive, but crudely developed horizontal stratification is visible locally (fig. 8A, left side of F3 bed). These characteristics, along with poorer sorting and the apparent absence of fluid escape structures, are the primary features that distinguish F3 from F2. Bioturbation was not recognized in F3 (BI 0).

\section{Interpretation}

F3 is interpreted as the product of sandy hyperconcentrated density flows (Mulder and Alexander, 2001). Some characteristics of F3 resemble the low-strength, non-cohesive, sandy debris-flow deposits of Talling and others (2012) and slurry-flow deposits of Lowe and Guy (2000). Fine sand- to cobble-sized particles were carried in concentrated suspensions supported by grain-tograin collisions, hindered settling, buoyancy and, to a limited degree, fluid turbulence. High sediment fallout rates supplied a traction carpet at the base of the flow that was subjected to abrupt frictional freezing as a sediment concentration threshold was exceeded, followed immediately by formation of a new traction carpet above. In this way, the depositional interface aggraded in a stepwise manner as the flow progressed and equilibrium bedforms were 
unable to develop. This process was described in detail by Lowe (1982) and Lowe and Guy (2000), and we envision a similar process was responsible for deposition of facies F3. Flows were able to erode the substrate over which they traveled as indicated by the presence of mudstone and muddy conglomerate rip-up clasts incorporated in most beds and minor erosional relief locally present at the base of beds.


Figure 8. Field photos showing characteristics of facies F3. A. Sandstone bed of F3 from $11.0 \mathrm{~m}$ to $13.7 \mathrm{~m}$. Note the pebbleand cobble-sized clasts "floating" in sandstone (white and black arrows). View is toward the north-northwest. B. Close-up view of the bed shown in A (at approximately $12 \mathrm{~m}$ ), showing the poorly sorted texture and scattered pebbles and cobbles. Notebook is $19 \mathrm{~cm}$ long. View is toward the north. C. Sandstone of F3 at $41 \mathrm{~m}$ with intraformational rip-up clasts of muddy conglomerate. Eraser leaning against muddy conglomerate clast is $12.5 \mathrm{~cm}$ long. View is toward the north. 
Only two examples of $\mathrm{F} 3$ were recognized in the exposure (11.0-13.8 $\mathrm{m}$ and $40.9-42.2 \mathrm{~m}$ in fig. 4). The example from $11.0-13.8 \mathrm{~m}$ includes a bed of F5, and is overlain by a turbidite and turbiditic or hemipelagic mudstone deposits (F1; fig. 4); the relation between F3 and F5 is unclear, and the overlying deposits are likely unrelated to the event that resulted in deposition of F3. The example from 40.9-42.2 $\mathrm{m}$ may be co-genetic with the overlying debrite (F6; fig. 4). Spheroidal pockets of muddy conglomerate and mudstone clasts in this bed represent intraformational clasts derived from facies F5 and mudstone not seen in the outcrop, respectively, as the hyperconcentrated flow traveled over beds of these facies, which indicates the flow was able to erode the underlying substrate, dislodging and incorporating cohesive blocks. The well-rounded, spheroidal to ellipsoidal shape of these clasts indicates they were able to move and roll relative to other particles.

\section{Facies 4 (F4): Clast-Supported, Sandy Pebble and Cobble Conglomerate Description}

F4 consists of poorly to moderately sorted, clast-supported, pebble and cobble conglomerate (figs. 9A-E). Beds appear tabular to broadly lenticular at outcrop scale and range from $0.2 \mathrm{~m}$ to over $1 \mathrm{~m}$ thick. The base of most beds is planar (fig. 9A), but relief up to $35 \mathrm{~cm}$ is present locally. Beds of F4 are abruptly overlain by sandstone of F2 (figs. 9A and 9B, and 9E) or conglomerate of $\mathrm{F} 5$ (fig. 9C). Light- to medium-green, poorly to moderately sorted, medium- to coarse-grained sandstone is present as matrix between clasts. Clasts are dominantly mafic to intermediate volcanic and plutonic lithologies, and most are characterized by equant shapes; rare platy to irregular mudstone intraclasts are locally present but appear absent in most beds. Massive and normally graded (coarse tail and distribution grading) beds seem equally common (figs. 9A and 9C). Clast fabrics in most beds appear random (fig. 9A), but weakly developed imbrication that indicates flow toward the east to southeast is present locally (figs. 9B and 9D); well-developed imbricate fabrics would not be expected given the equant shape of most clasts. Trace fossils and bioturbation fabrics were not recognized (BI 0).

\section{Interpretation}

F4 is the product of concentrated density flows in which coarse pebble- and cobble-sized clasts were transported as part of a traction carpet (Mulder and Alexander, 2001). Examples of F4 overlain by sandstone of F2 in which pebble stringers can be traced down-section from F2 sandstone into F4 conglomerate clearly demonstrate that these two facies are the result of the same flow event and are co-genetic. F4-F2 couplets suggest the parent flows included high concentrations of sand in suspension above gravelly traction carpets. Deposition of the gravel was by frictional freezing with little or no subsequent clast movement beneath the flow. This contributed to the general lack of clast imbrication along with the equant shape of most clasts. Although sand and gravel were largely partitioned in these flows, the presence of poorly to moderately sorted sandy matrix in F4 suggests that some sand was transported with the gravel in traction carpets.

\section{Facies 5 (F5): Clast-Supported, Muddy Pebble and Cobble Conglomerate Description}

F5 consists of very poorly to poorly sorted, muddy, clast-supported, pebble and cobble

Figure 9, following page. Field photos showing characteristics of facies F4. A. Normally graded bed of pebble conglomerate at $14 \mathrm{~m}$. Hammer is $42 \mathrm{~cm}$ long. B. Ungraded bed of pebble conglomerate at $40.3 \mathrm{~m}$. Note sandstone bed of F2 abruptly overlying conglomerate. F2 and F4 were likely deposited from the same event. Notebook is $19 \mathrm{~cm}$ long. C. Ungraded bed of F4 at 27.1 $\mathrm{m}$. Note pebbly mudstone of F6 below the bed and F5 above. Rock hammer is $30 \mathrm{~cm}$ long. D. Ungraded pebble conglomerate at $62 \mathrm{~m}$. Note weakly developed imbrication. Lens cap is $4.2 \mathrm{~cm}$ in diameter. E. Upper part of bed showing transition from F4 to F2. Note lenses of sandstone within F4 (black arrows). Geologist is $1.85 \mathrm{~m}$ tall and his left hand is at approximately $16 \mathrm{~m}$ in the composite measured section in figure 4. View in all photos except $E$ is toward the north; view in $E$ is toward the northwest. 

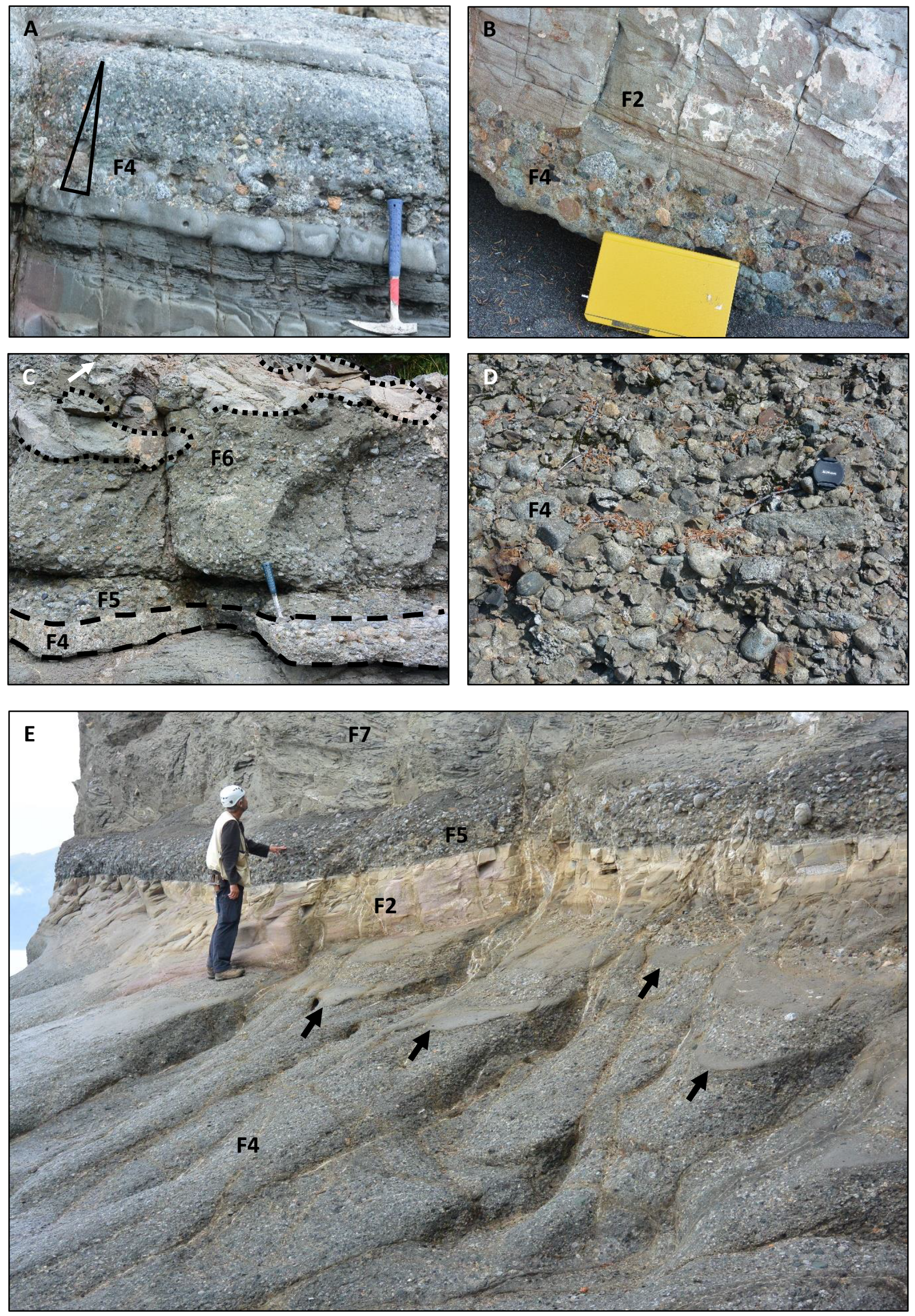
conglomerate (figs. 10A-G). Beds range in thickness from $10 \mathrm{~cm}$ to approximately $1.0 \mathrm{~m}$. Small boulder-sized clasts are present locally. Most beds are ungraded (fig. 10E), but crudely developed inverse grading and coarse-tail normal grading are developed locally (figs. 10B, 10C, and 10D, respectively). Where present, inverse grading is limited to the lower $4-20 \mathrm{~cm}$ of the bed (fig. 10B). Matrix consists of poorly sorted, medium- to darkgreen mudstone. Mafic to intermediate plutonic and volcanic rocks and minor intraformational clasts (mudstone and sandstone) compose the clast population. Most clasts have an equant shape and appear randomly oriented (figs. 10A-F). Beds of F5 rest above a sharp contact with underlying sandstone, and the contact with overlying muddy facies (F6 or F7) is typically sharp (figs. 10A, 10D, and $10 \mathrm{E}$ ); however, a gradational upper contact is present where the overlying bed is F6 and clast-rich (fig. 10F). Disarticulated bivalve shells are present in some beds of F5 (fig. 10H). Trace fossils and bioturbation fabrics were not recognized (BI 0).

\section{Interpretation}

F5 records deposition from concentrated debris flows. Deposition occurred en masse when shear stress dropped below the yield strength of the mass (Hampton, 1972; Lowe, 1979, 1982; Mulder and Alexander, 2001). Prior to deposition, clasts were supported by a combination of matrix strength and buoyancy (Mulder and Alexander, 2001). The clast-supported texture indicates the concentration of clasts in these flows was high enough that dispersive pressure (grain-to-grain collisions) was likely also an important contributor to clast support. The flows responsible for transporting pebble-, cobble-, and boulder-sized clasts in F5 operated on relatively steep slopes where the applied shear stress would have been high enough to overcome yield strength and maintain dispersive pressure (Walker, 1975). Deposition was likely initiated by an abrupt decrease in slope gradient that resulted in a reduction in applied shear stress and flow competence, and abrupt freezing of the flow. The presence of disarticulated pelecypod valves (molds and casts) suggests at least some of the sediment in F5 was derived from shelf staging areas.

\section{Facies 6 (F6): Matrix-Supported, Pebbly-Cobbly-Bouldery Mudstone Description}

F6 consists of muddy, matrix-supported, clast-rich to clast-poor, pebble-cobble-boulder conglomerate (fig. 11A, 7A). Bed thickness ranges from $1 \mathrm{~m}$ to over $4 \mathrm{~m}$. Matrix consists of graygreen mudstone and clast composition is similar to F4 and F5 with the conspicuous addition of intraformational clasts of sandstone in most beds (fig. 11A-D). Poorly developed reverse grading is present locally (fig. 11B). Sandstone clasts range in size from pebbles to tabular blocks (or rafts) 1.0 $\mathrm{m}$ thick and up to $4 \mathrm{~m}$ long (apparent long axis parallel to outcrop face; figs. 11A-C). Some beds have sandstone clasts throughout their thickness (figs. 11C-D) while others have sandstone blocks concentrated at specific stratigraphic levels (fig. 11B). Sandstone blocks consist of broken beds resembling F2 or, sometimes, F3. Cobble- and small boulder-sized sandstone clasts display a range of soft-sediment deformation features including rounded clast morphologies and complex folds (fig. 11D). Similarly, sandstone rafts display a range of deformation features including tabular blocks that are internally undeformed but have rounded edges (fig. 11C) to blocks that have a jumbled, chaotic appearance (figs. 11A and 11B). Body fossils were not observed in F6. Bioturbation is generally absent (BI 0), but rare, vertical, sand-filled shafts are present that extend downward into F6 from overlying sandstone beds of F2. Textures recognized in F6 closely resemble pebbly mudstones

Figure 10, following page. Field photos showing characteristics of facies F5. A-G. Examples of facies F5 showing texture and contact relations with bounding facies. Base of F5 bed in C is $15.7 \mathrm{~m}$; base of F5 bed in D is a few centimeters below 32 $\mathrm{m}$; base of F5 bed in E is $26.7 \mathrm{~m}$; base of F5 bed in F is $27.3 \mathrm{~m}$; base of F5 in G is the same as in D. Notebook is $19 \mathrm{~cm}$ long, hammer is $42 \mathrm{~cm}$ long, and tape measure is $6 \mathrm{~cm}$ wide. $\mathbf{H}$. Disarticulated pelecypod valves in muddy matrix at $37 \mathrm{~m}$. 

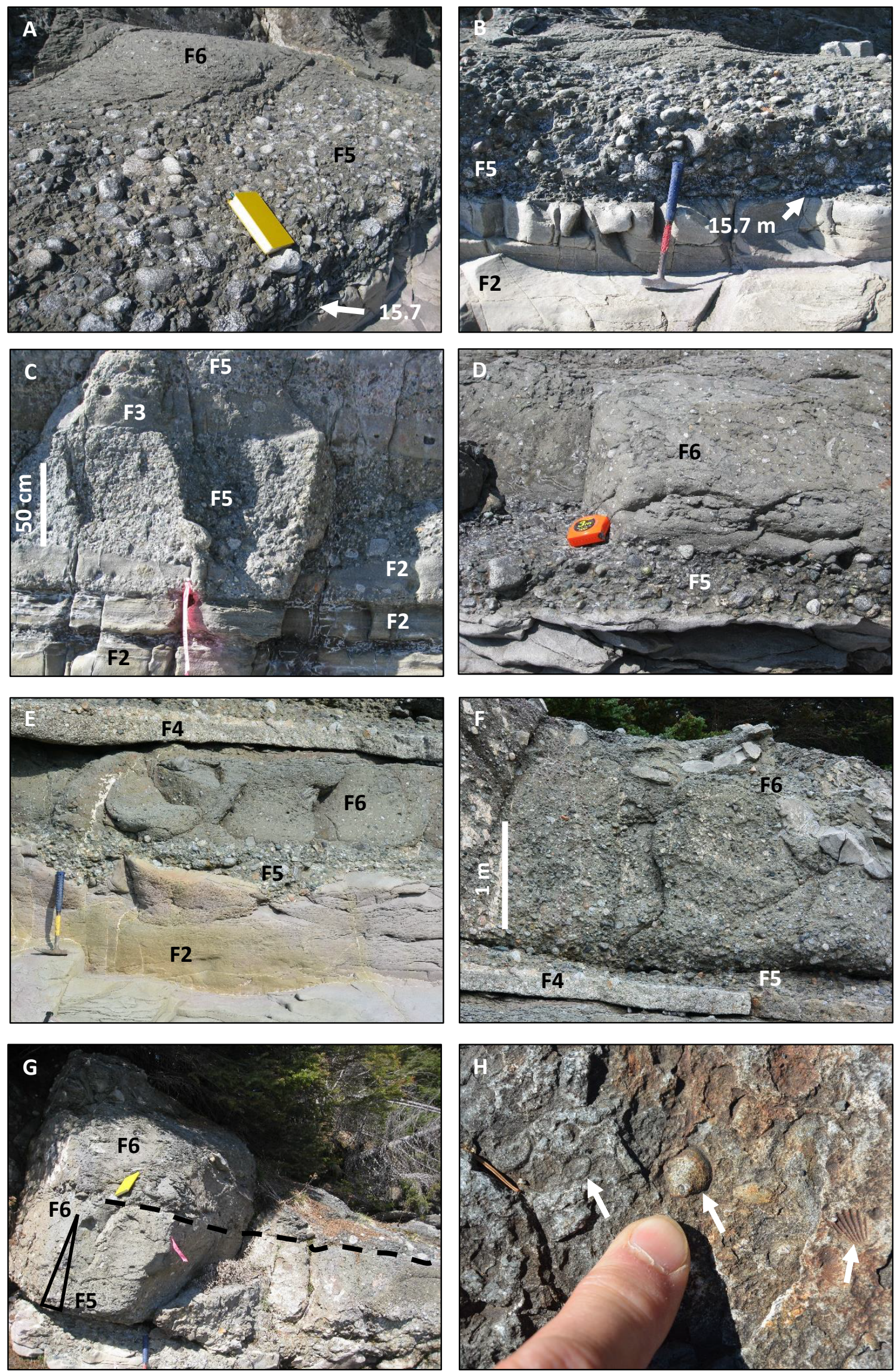
documented by Crowell (1957), particularly those exposed along the California coast at Pigeon Point (see Lopez-Gamundi, 1993).

\section{Interpretation}

F6 was deposited from clast-poor (relative to F5) debris flows. Deposition was initiated en masse when the applied shear stress dropped below the yield strength of the sediment-water mixture (Hampton, 1972; Locat and Lee, 2005; Mulder and Alexander, 2001). The combination of high debris (matrix) density (close to the density of the sandstone rafts) provided sufficient buoyancy in some flows to help support blocks of sandstone up to 1 $\mathrm{m}$ thick and at least $4 \mathrm{~m}$ long (Rodine and Johnson, 1976; Leigh and Hartley, 1992). Matrix strength also contributed to clast support. Intraformational blocks of sandstone were incorporated in the flows basinward of the shelf edge, either at their point of origin or at locations along their flow paths. Deformation features documented in sandstone clasts and blocks indicate the sandstones were compacted, but not lithified, at the time they were incorporated into flows. As in F5, deposition was most likely initiated by an abrupt decrease in slope gradient.

\section{Facies 7 (F7): Chaotically Bedded Mudstone Description}

F7 is highly deformed and consists of sandy mudstone with thin interbeds of fine- to medium-grained sandstone (figs. 12A and 12B). Pebbleand cobble-sized clasts of mafic and intermediate igneous rocks are present locally in mudstone, as are similarly sized intraformational clasts of sandstone. Faint stratification is visible in the mudstone and is often defined by thin beds of sandstone. Deformation ranges from boudinaged sandstone beds to recumbently folded beds of sandstone and faintly stratified mudstone (fig. 12A-B, including inset photos). Some detached, soft-sediment-deformed sandstone blocks similar to those in F6 are present locally (fig. 12A inset photo). Deformation is limited to $\mathrm{F} 7$ and, other than a modest tectonic dip, bounding beds are not deformed (figs. 12A, 12C, and 12D). The presence of faintly visible stratification and boudinaged sandstone beds are the main features that distinguish F7 from F6. Similar textures have been recognized in the Pigeon Point Formation in California by Lopez-Gamundi (1993).

\section{Interpretation}

F7 represents subaqueous slide deposits in which most slide masses were internally sheared and deformed, but not to the point of total disintegration to form cohesive debris flows (Lopez-Gamundi, 1993; Mulder and Cochonat, 1996). As such, F7 is interpreted as intact translational slide masses (glide mass in Nardin and others' (1979) classification scheme) that came to rest just short of the point of total disintegration. The presence in close proximity within the same slide mass of thin, boudinaged sandstone beds and blocks of folded sandstone in a mudstone matrix documents this transition (fig. 12A).

\section{DEPOSITIONAL PROCESSES}

The facies analysis in the preceding section provides the information necessary to infer linked depositional processes and to reconstruct the depositional setting. The lower $9 \mathrm{~m}$ of the exposure consists of thinly interbedded sandstones and mudstones of $\mathrm{F} 1$, which are interpreted to record deposition from low-volume, largely non-erosive, surge-like turbidity currents (Mulder and Alexander, 2001) in a lower slope to proximal basin

Figure 11, following page. Field photos showing characteristics of facies F6. A, B. Thin bed of F5 (base at $27.3 \mathrm{~m}$ ) that grades upward over a short distance to F6. Note poorly developed inverse grading of the largest clasts in F5. Note also the sharp contact between F4 and F5. F5 and F6 are co-genetic; bed of F4 is interpreted as the deposit of a co-genetic concentrated density flow that ran out in front of the debris flow responsible for F5 and F6. See text for additional discussion. Hammer in A is $42 \mathrm{~cm}$ long and staff in B is marked in $10 \mathrm{~cm}$ increments. View toward the northwest. C. Large blocks (rafts) of sandstone similar to F2 in mudstone of F6 from $48.1 \mathrm{~m}$ to approximately $50 \mathrm{~m}$. Mudstone includes scattered pebbles and small sandstone intraclasts, and complex soft-sediment folds. View is toward the northwest. D. Close-up view of F6 at $27 \mathrm{~m}$ showing cobble- to boulder-sized intraformational clasts of folded sandstone in a pebbly mudstone matrix. Hammer is $42 \mathrm{~cm}$ long. 

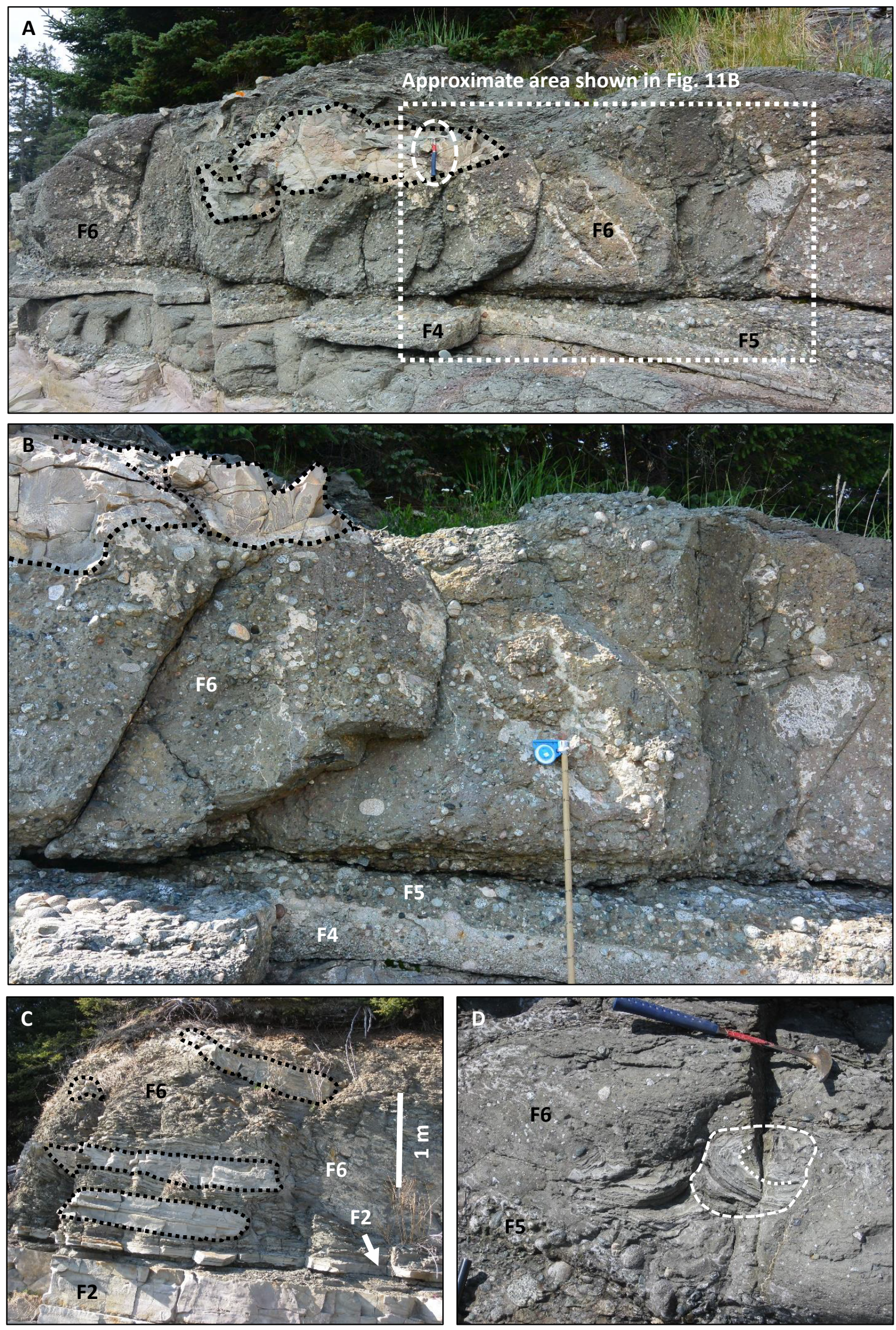
floor setting. The abrupt decrease in the average grain size of mudstone and in the number of sandstone beds above $2.7 \mathrm{~m}$ (fig. 4) marks an abrupt reduction in sediment supply, possibly the result of an avulsion event in a coeval depositional setting located landward (west to west-northwest in present-day coordinates), such as a delta that previously delivered sediment to the shelf edge. A prominent surface at $9 \mathrm{~m}$ visible in low-altitude oblique aerial photos truncates several thin sandstone beds (fig. 13). This surface is likely a slide detachment plane, and the associated MTD is not preserved in the outcrop (fig. 4) but was transported an unknown distance basinward from this location.

A small channel-form feature at least $60 \mathrm{~m}$ wide and filled with approximately $4 \mathrm{~m}$ of amalgamated sandstones of F2 is present in the intertidal zone immediately south of our measured section (figs. 13 and 14). A minor shear zone is coincident with the northern border of the channel sand body and separates it from a sand-rich variant of F1 immediately to the north. The detachment surface at $9 \mathrm{~m}$ truncates the sand-rich variant of F1 in the composite measured section and can be traced southward, where it ramps up-section and corresponds roughly with the top of the channel sand body (figs. 4 and 13). We interpret the channel-form feature as a small slope gully that served as a conduit for relatively small-volume density flows, the last several of which filled the gully. The significance of these facies relations is unclear, but the gully-fill and sand-rich variant of F1 is interpreted as a small leveed channel deposit (leveed gully). Outcrop relations indicate the leveed gully developed prior to the mass-wasting event responsible for the detachment surface. This gully appears comparable, or slightly smaller, in size to small slope channels recognized in Spitsbergen by Plink-Bjorklund and others (2001) and Petter and Steel (2006).

The detachment surface at $9 \mathrm{~m}$ signals an abrupt change in facies architecture starting at 11 $\mathrm{m}$ (figs. 4 and 13). The remaining succession is $52.2 \mathrm{~m}$ thick and mainly comprises concentrated density flow deposits and MTDs; dilute turbidites of $\mathrm{F} 1$ are relatively rare and only recognized in two thin intervals (fig. 4). Facies characteristics and stacking patterns in this part of the exposure demonstrate genetic links between several facies, which are discussed below.

Clast-supported conglomerate of F4 and sandstone of F2 commonly comprise couplets that record deposition from stratified, fluidal flows. The base of these flows consisted of a traction carpet in which pebble- to cobble-sized clasts were transported (F4); above the traction carpet was a concentrated suspension of very fine- to coarse-grained sand supported by dispersive pressures, buoyancy and, to a limited degree, turbulence (F2). Deposition of both was likely initiated by an abrupt decrease in gradient, such as would be expected at the base of a prominent slope that promoted a reduction in shear stress in the traction carpet and subsequent frictional freezing and a loss of competence in the overlying suspension. The sand fallout

Figure 12, following page. Field photos showing characteristics of facies F7. A. Bed of F7 from $16.9 \mathrm{~m}$ to $23.9 \mathrm{~m}$. Note the thin, boudinaged sandstone beds (black arrows) dipping toward geologist. Inset photograph shows isoclinal, recumbent-folded sandstone in same bed. Geologist's head for scale in lower left corner of inset photograph. View is toward the north. B. Complexly deformed bed of F7 from $34 \mathrm{~m}$ to $36.9 \mathrm{~m}$ (field of view includes beds up to $41 \mathrm{~m}$ in fig. 4). Contact between F7 and F2 is immediately above geologist's left shoulder. Inset photograph shows complex folding in interbedded sandstone and mudstone. The characteristics of this bed suggests it represents a slide mass that was complexly deformed in the transport process but was not completely transformed through disaggregation to a debris flow. View is toward the northeast. C. Train of open folds in mudstone of F7 at $45.7 \mathrm{~m}$ (contact with F2 bed). Bed of F4 shown in figure 4 at approximately $45.8 \mathrm{~m}$ pinches out laterally and is not present at this location. Hammer (dashed red oval) is $42 \mathrm{~cm}$ long. F7 in this example is interpreted to be co-genetic with the underlying bed of F3 (not shown, see top at $42.2 \mathrm{~m}$ in fig. 4), which is interpreted as the deposit of a hyperconcentrated flow phase that outran the slide mass. View is toward the northwest. D. Same stratigraphic level as shown in 12C but located several meters away along strike of outcrop. Note the sandstone bed on the limb of a soft-sediment fold that is truncated at the base of the overlying bed of F2. View is toward the northwest. 

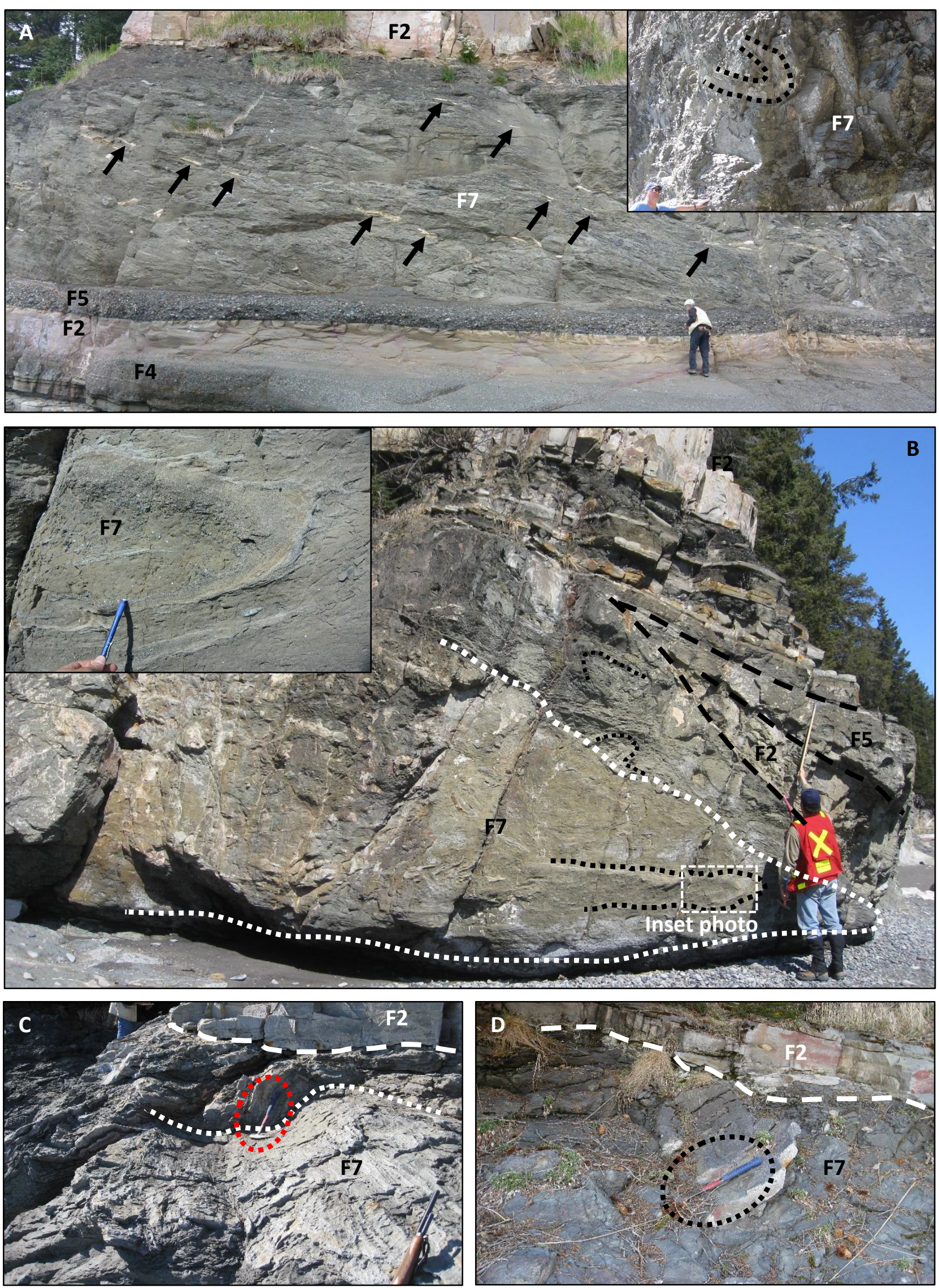

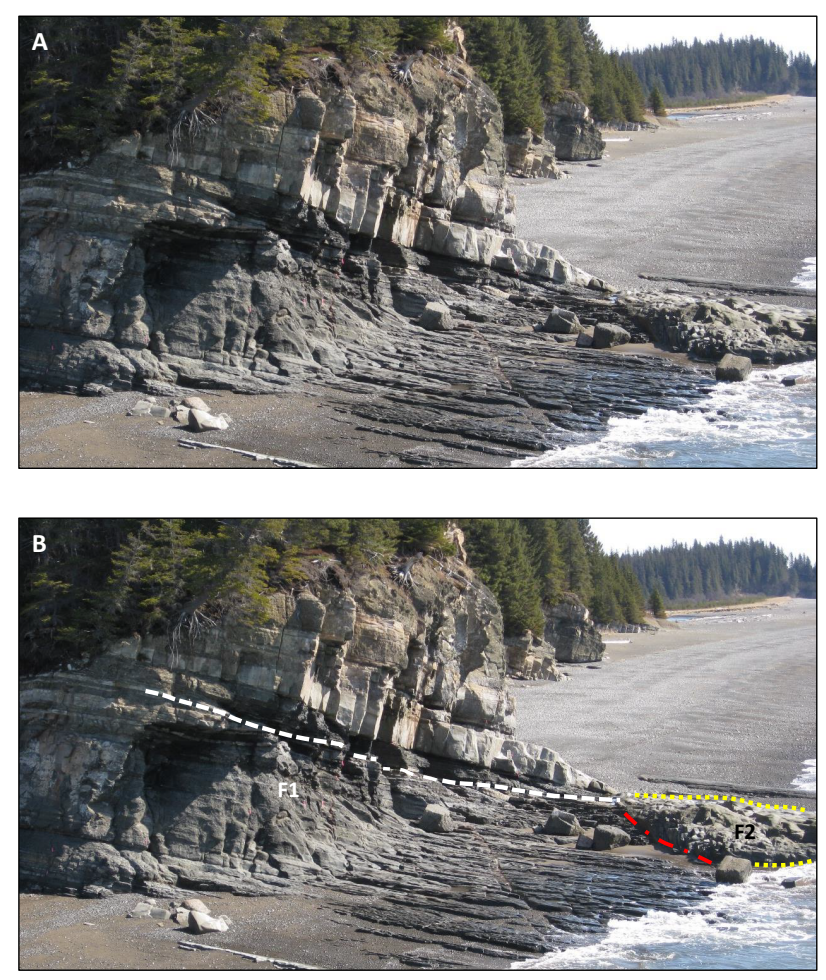

Figure 13. Low-altitude, oblique air photo of the lower $25 \mathrm{~m}$ of the section shown in figure 4. View is toward the northeast. A. Uninterpreted photo. B. Same photo as in A. showing trace of detachment surface (dashed white line) that intersects the composite measured section at 9 $\mathrm{m}$. Dashed red line marks the sheared northern margin of the gully-fill; the base and top of the gully-fill are shown by the dotted yellow lines. Note the stratigraphy shown is essentially the same as figure 3A. Note also the truncation of thin beds of $\mathrm{F} 1$ at the surface marked by the dashed white line. This feature is interpreted as a detachment surface for a slide mass.

rate from these flows was high, promoting rapid aggradation of the depositional interface with little or no subsequent traction transport (Lowe, 1988). The local presence of horizontal lamination indicates the fallout rate from some flows at some locations was low enough that sand could effectively be transported as bedload in a traction carpet, allowing crude horizontal stratification to form (Lowe, 1988). The presence of ripple cross-lamination in several beds near the top of F2 shows that small, equilibrium bedforms (current ripples) developed during the waning stages of flow events when most sand-sized detritus had settled out of suspension, but shear stress between the flow and sediment surface was still great enough to move sand finer than medium grade. Facies relations suggest that some F2 and F4 beds beneath MTDs were deposited from flows that were co-genetic with the mass-wasting events responsible for the overlying deposits.

Some MTDs in the studied succession typically include, from base to top, clast-supported, muddy conglomerates (F5) and matrix-supported, pebbly-cobbly-bouldery mudstones (F6); some MTDs are capped by a deformed slide mass (F7). These facies are interpreted as co-genetic deposits of relatively small, retrogressive mass-wasting events. The transition from F5 to F6 is typically abrupt but does not appear erosional nor to represent a detachment surface; where F7 is present, it is gradational above F6. This facies stacking order and vertical contact relationship suggest the following origin and evolution for most MTDs in the exposure: 1) A slide was generated upslope by some triggering mechanism. 2) As the slide mass moved down slope, internal shear stresses and mixing along the margins resulted in complete disaggregation and formation of a debris flow. 3) Shear stress at the base of the debris flow further concentrated pebble- to small boulder-sized extrabasinal clasts in a basal, clast-supported shear layer recorded in F5, with the main part of the debris flow represented by matrix-supported pebbly mudstone of F6 (fig. 15A). Finally, the presence of large rafts of intrabasinal sandstone in F6 attests to the ability of the matrix to support large clasts via matrix strength and buoyancy.

The parent slide masses are preserved in a few of the MTDs in the studied succession, where they occur as a cap of F7 and F6 above a lower succession of F5 and F6 (fig. 4, approximately 17-23.8 m, 28.7-29.8 $\mathrm{m}, 33.6-36.9 \mathrm{~m})$. As the slide masses that formed these MTDs moved down slope, internal shear stresses deformed the original stratigraphy in the slide blocks, which in some areas resulted in tensional strain that produced boudinaged beds (fig. 12A). In other areas of the same masses, compressional strain is recorded in folded beds that include upright, open 


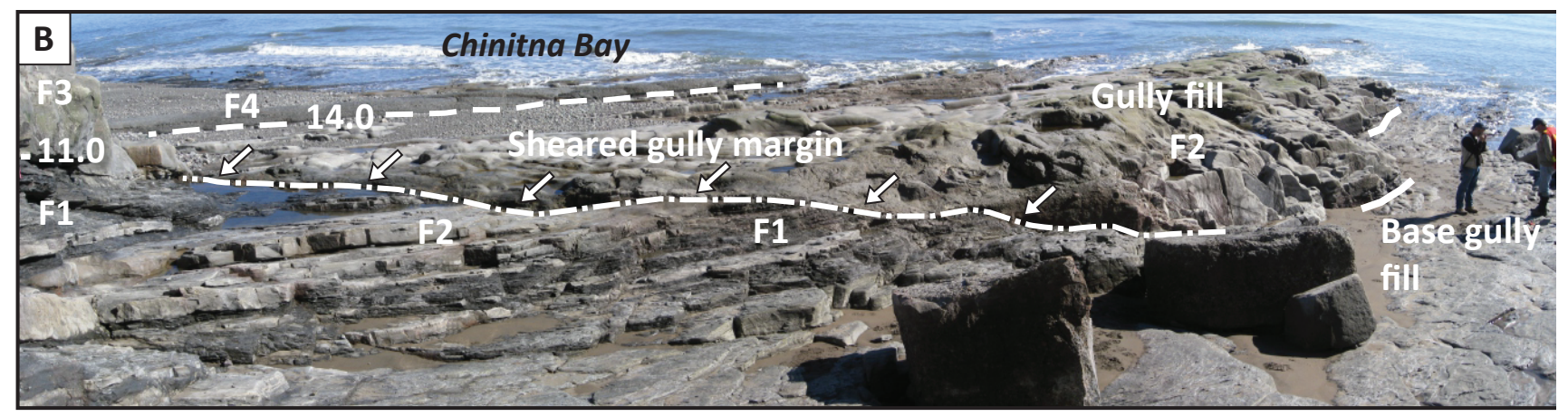

A.

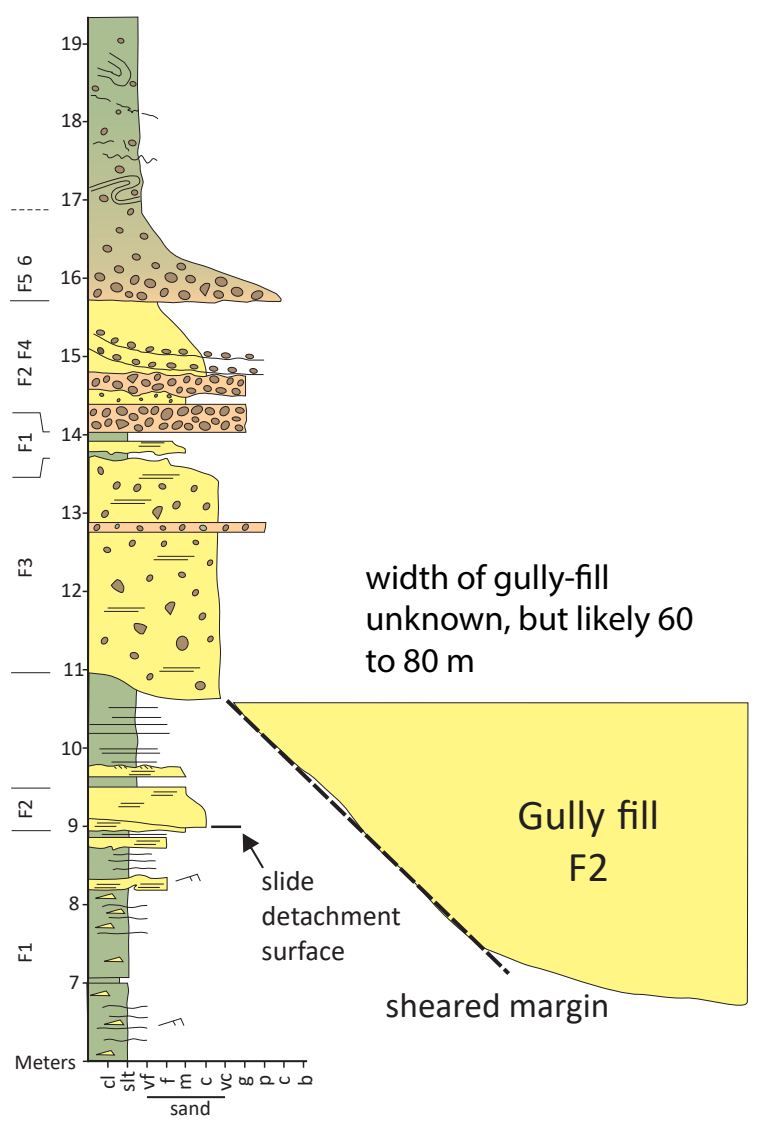

folds; over-turned, open folds; isoclinal folds; and isoclinal recumbent folds (fig. 12A inset), but a core volume of the masses remained essentially intact as slides (F7). In these MTDs the slide masses appear to have ridden atop muddy debris layers (F5 and F6; fig. 15B). The muddy character of the debris layer may have helped maintain elevated pore pressures that assisted in supporting slide masses in a manner similar to the mechanism invoked by Leigh and Hartley (1992) to explain large blocks in very thick debrites from the Pindous Basin in Greece. The facies succession $\mathrm{F} 5 \rightarrow \mathrm{F} 6 \rightarrow \mathrm{F} 7$ in some of the MTDs
Figure 14. Outcrop relations between facies in composite measured section and channel-form body exposed in the intertidal zone. A. Lower $19 \mathrm{~m}$ of section shown in figure 4, illustrating the relationship between the main exposure of MTDs and associated strata, and a small gullyfill feature exposed in the intertidal zone. The top of the gully fill corresponds approximately to $11 \mathrm{~m}$ in figure 4 . B. Photograph showing facies relations between the channelform body (gully fill) and F1 and F2 immediately to the north. The dashed white line corresponds to the sheared northern margin of the channel body. Note the two geologists at the right edge of the photograph for scale.

provides convincing evidence that they are cogenetic and were derived from the progressive disintegration of slide masses. A similar range of textures has been recognized in the Pigeon Point Formation in California and was similarly interpreted as representing the mechanical transition from slumps (Lopez-Gamundi's term) to cohesive debris flows (Lopez-Gamundi, 1993). We suggest that where F2, F3, and F4 underlie MTDs, they also could be cogenetic.

Muddy conglomerates of F5 are absent at the base of the MTD from 42.2 to $45.8 \mathrm{~m}$ (fig. 4). The 


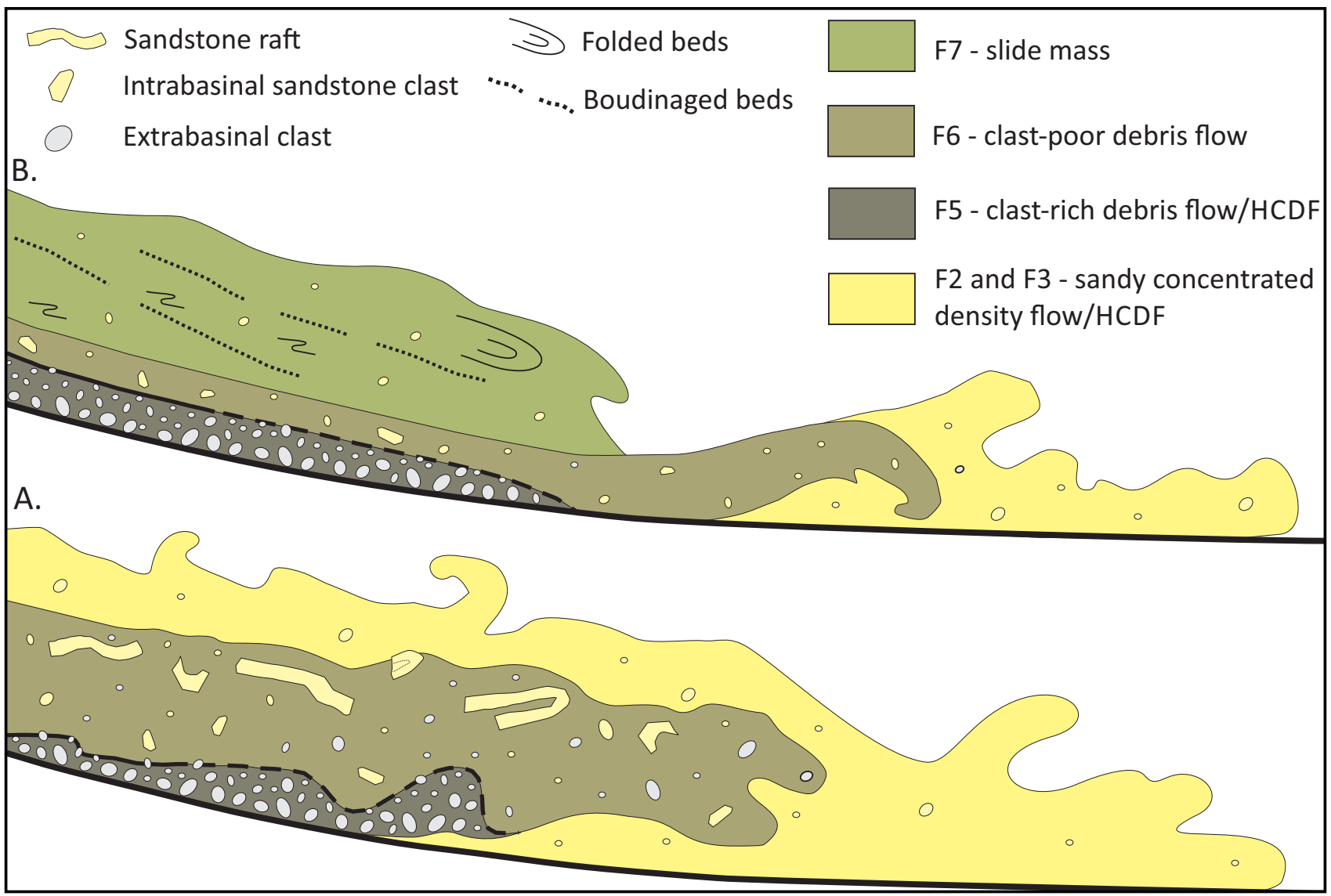

Figure 15. Cartoons showing the interpreted co-genetic origin of facies F2/F3, F5, F6, and F7. A. Facies sequence F2/ $\mathrm{F} 3 \rightarrow \mathrm{F} 5 \rightarrow \mathrm{F} 6 \pm \rightarrow F 2 / F 3$. B. Facies sequence F5 $\rightarrow$ F6 $\rightarrow$ F7. See text for discussion. HCDF = hyperconcentrated density flow.

underlying pebbly sandstone of F3 (from 40.9 to $42.2 \mathrm{~m})$ most likely comprises a depositional unit that is genetically linked to the overlying MTD (F6). In this mass-wasting event, the F3 bed is interpreted as a hyperconcentrated density flow that developed by mixing at the front of the slide, which it subsequently outran, and was deposited, and ultimately buried beneath the MTD (fig. 15A). The overlying MTD is a highly deformed mass comprising a jumbled mix of mudstone and sandstone rafts of F6 that record the complete disintegration of the slide mass, forming a debris flow.

\section{DISCUSSION}

The succession of MTDs and associated deposits documented in this report records a series of relatively small mass-wasting events that originated in a shelf-edge, slope, or proximal basin-floor setting (fig. 16). The repetitive facies stacking pattern evident in outcrop (fig. 4) suggests that retrogressive slope failures (Hampton and others, 1996, p. 34) may have been responsible for the observed MTDs. The source area for these failures may have been the seaward-facing slope, the headwalls and sidewalls of a submarine canyon that incised the slope, or the sidewalls of a large leveed channel in the proximal part of a slope apron. Recent mapping and stratigraphic studies in the region by DGGS suggest that a distinct shelf-slope break had developed along the arc side of the forearc basin by Late Jurassic time, and that the outer shelf and slope were cut by canyon-scale incisions (fig. 16; Herriott and others, 2017). Mountain-side exposures through these features reveal they were subsequently filled with a spectrum of deepwater facies including MTDs (Herriott and others, 2017). Given the two-dimensional, dip-oblique orientation of the exposure addressed in this report, it is impossible to know 


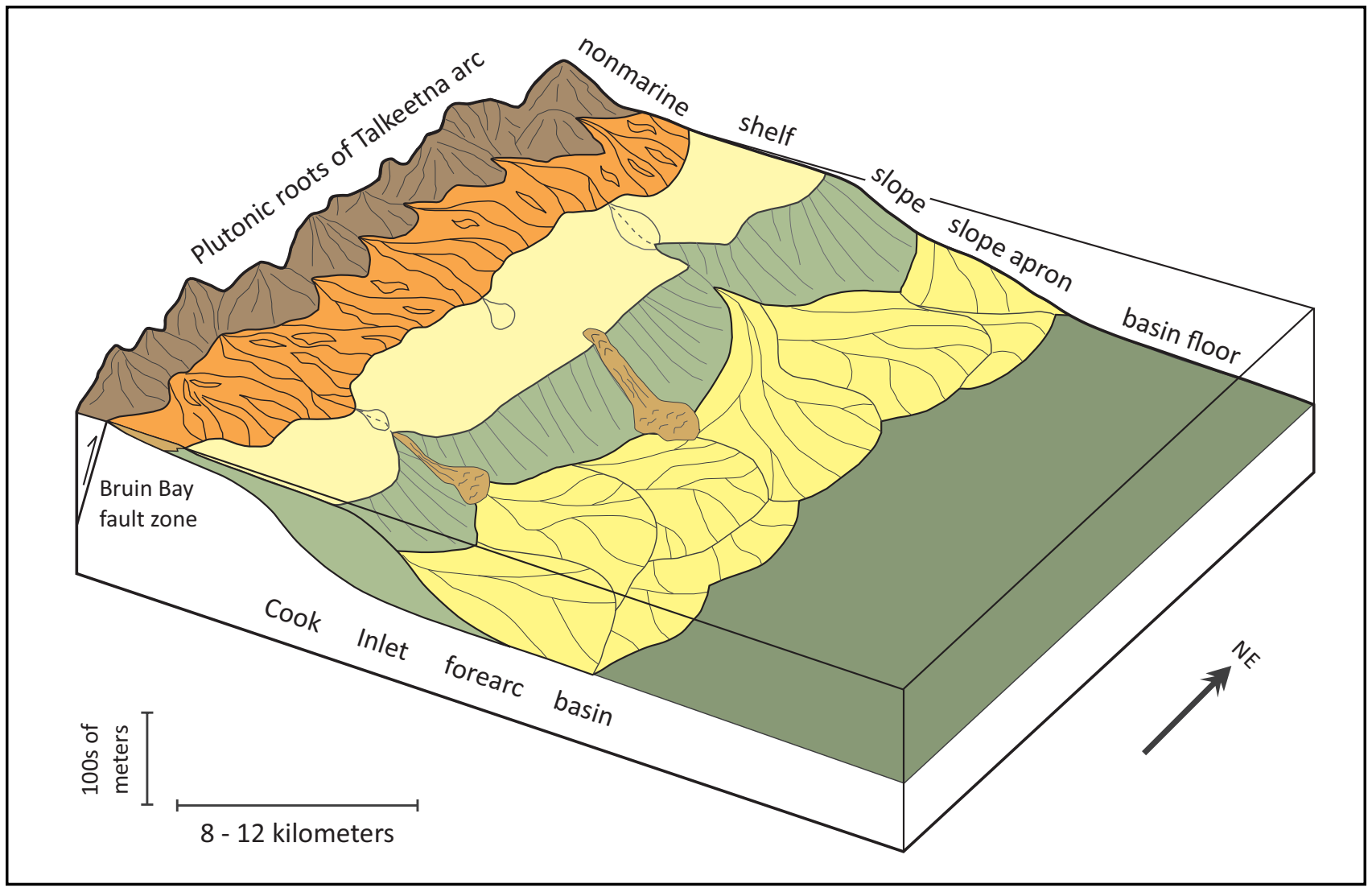

Figure 16. Block diagram showing the inferred depositional setting of the mass transport deposits (shown in medium brown color) exposed near Clam Cove. Mass transport deposits are shown as tongue-shaped masses within submarine canyons and as unconfined deposits in slope and base-of-slope settings. The exposure at Clam Cove is too limited in strike extent to determine if the slide deposits are confined within a submarine canyon or are in an unconfined slope to base-of-slope setting. Figure modified from Herriott and others (2017) and Reading and Richards (1994).

with certainty if the succession is part of the fill of a slope canyon, a large channel in a slope apron setting, or a series of MTDs that originated along an unconfined slope. The abundance of clast-supported pebble- and cobble-conglomerate of F4 and amalgamated sandstones of F2 argue against an unconfined slope setting, but rather suggest deposition in a confined slope canyon or large channel in a proximal slope apron setting (or a large channel within a canyon). Conglomerates of F4 suggest traction transport along the thalweg of relatively steep-gradient channels where shear stresses would have been high enough to move a traction carpet of pebbleand cobble-sized gravel.

The stratigraphic organization of the Naknek Formation in the Tuxedni Bay-Iniskin Bay region records a gradual upward-deepening from shore zone and shelf to slope and base-of-slope depositional settings (LePain and others, 2013, their fig. 3a; Wartes and others, 2015; Herriott and others, 2017). Thick tabular beds of sandstone with minor interbedded mudstone make up much of the Pomeroy Arkose Member in the region, and are interpreted to represent a sand-rich slope-apron system (fig. 16). The base of the exposure addressed in this report consists largely of classic thin-bedded sandstone turbidites and interbedded mudstones (facies F1) and does not resemble the thick, tabular beds so characteristic of the Pomeroy in the region. This suggests F1 was deposited after the sand-rich slope apron system was abandoned in this area.

Mass-transport deposits are commonly associated with the falling stage and low stand systems tracts (Posamentier and Walker, 2006; Weimer 
and Slatt, 2007). During these times, deltas can prograde to locations on the outer shelf and upper slope (Posamentier and Allen, 1999). When combined with high sediment supply, a wedge of rapidly deposited, relatively coarse-grained sediment results that can be perched at the shelf edge or on the upper slope. By virtue of their position at the shelf edge and upper slope, these wedges are highly susceptible to mass-wasting triggered by cyclic loading associated with powerful storm waves and earthquakes (Stow and others, 1996; Weimer and Slatt, 2007). Given the deepwater depositional setting, it is difficult to distinguish between these mechanisms; however, the forearc basin setting and proximity to the Bruin Bay fault zone-which is known to have been active during the Late Jurassic — makes seismicity a likely trigger for the mass-wasting events recorded in the uppermost Pomeroy Arkose Member on the north shore of Chinitna Bay.

\section{ACKNOWLEDGMENTS}

This work was funded by the State of Alaska. Helicopter pilots George Tickner, Merlin "Spanky" Handley, and Mike Brandau of Pathfinder Aviation transported us safely each day to and from the north shore of Chinitna Bay. James and Sheila Isaaks of Alaska Homestead Lodge kept us warm and well fed during the 2010 field season, and the owners and staff of Bear Mountain Lodge and Snug Harbor Lodge did the same in 2014 and 2017, respectively. We acknowledge Lake Clark National Park and Preserve for granting permits to access parts of the outcrop situated above mean high tide. We gratefully acknowledge our co-workers, Bob Gillis, Nina Harun, Trystan Herriott, and Marwan Wartes for sharing their insights regarding the geology of the Iniskin-Tuxedni region and the sedimentology of the Naknek Formation. We thank Dave Buthman, Nina Harun, and Trystan Herriott for reviewing the manuscript and making suggestions for its improvement.

\section{REFERENCES}

Bouma, A.H., 1962, Sedimentology of some flysch deposits: a graphic approach to facies interpretation: Amsterdam, Elsevier, 168 p.

Crowell, J.C., 1957, Origin of pebbly mudstones: Geological Society of America Bulletin, v. 68, p. 993-1,010.

Detterman, R.L., and Hartsock, J.K., 1966, Geology of the Iniskin-Tuxedni region, Alaska: U.S. Geological Survey Professional Paper 512, 78 p., 6 sheets, scale 1:63,360.

Detterman, R.L, and Westermann, G.E.G., 1992, Southern Alaska, in Poulton, T.P., Detterman, R.L., Hall, R.L., Jones, D.L., Peterson, J.A., Smith, P., Tayler, D.G., Tipper, H.W., and Westermann, G.E.G., Western Canada and United States, in Westermann, G.E.G., ed., The Jurassic of the Circum-Pacific, World and regional geology: Cambridge University Press, v. 3, p. 49-57.

Dott, R.H., 1963, Dynamics of subaqueous gravity depositional processes: American Association of Petroleum Geologist, Bulletin, v. 47, p. 104-128.

Field, M., and Clark, S.H., 1979, Small-scale slumps and slides and their significance for basin slope processes, southern California borderland, in Doyle, L.J., and Pilkey, O.H., eds., Geology of Continental Slopes: Society of Economic Paleontologists and Mineralogists, Special Publication 27, p. 223-230.

Folk, R.L., 1980, Petrology of Sedimentary Rocks: Hemphill, Austin, TX, 184 p.

Follmi, K.B., and Grimm, K.A., 1990, Doomed pioneers: gravity-flow deposition and bioturbation in marine oxygen-deficient environments: Geology, v. 18, p. 1069-1072.

Hampton, M.A., 1972, The role of subaqueous debris flow in generating turbidity currents: Journal of Sedimentary Petrology, v. 42, p. 775-793.

Hampton, M.A., Lee, H.J., and Locat, J., 1996, Submarine landslides: Reviews of Geophysics, v. 34, p. 33-59. 
Helmold, K.P., LePain, D.L., Wilson, M.D., and Peterson, C.S., 2013, Petrology and reservoir potential of Tertiary and Mesozoic sandstones, Cook Inlet, Alaska: A preliminary analysis of outcrop samples collected during 2007-2010 field seasons: Alaska Division of Geological \& Geophysical Surveys Preliminary Interpretive Report 2013-5, 34 p. http://doi. org/10.14509/25035

Helmold, K.P., Wartes, M.A., Gillis, R.J., LePain, D.L., Herriott, T.M., Stanley, R.G., and Wilson, M.D., 2018, Secular changes in Cenozoic arc magmatism recorded by trends in forearc-basin sandstone composition, Cook Inlet, southern, Alaska, in Ingersoll, R.V., Lawton, T.F., and Graham, S.A., eds., Tectonics, Sedimentary Basins, and Provenance: A Celebration of William R. Dickinson's Career: Geological Society of America Special Paper 540, p. 591-615

Herriott, T.M., Wartes, M.A., and Decker, P.L., 2017, Deep-water canyons and sequencestratigraphic framework of the Upper Jurassic Naknek Formation, south-central Alaska: Alaska Division of Geological \& Geophysical Surveys Report of Investigation 2017-4, 53 p. http://doi. org/10.14509/29707

LePain, D.L, Stanley, R.G., Helmold, K.P., and Shellenbaum, D.P., 2013, Geologic framework and petroleum systems of Cook Inlet basin, south-central Alaska, in Stone, D.M., and Hite, D.M., eds., Oil and Gas Fields of the Cook Inlet Basin: American Association of Petroleum Geologists Memoir 104, p. 37-116.

Leigh, S., and Hartley, A.J., 1992, Mega-debris flow deposits from the Oligo-Miocene Pindo foreland basin, western mainland Greece: Implications for transport mechanisms in ancient deep marine basins: Sedimentology, v. 39, p. 1,003-1,012.

Locat, J., and Lee, H.J., 2005, Subaqueous debris flows, in Jakob, M., and Hungr, O., eds., Debrisflow Hazards and Related Phenomena: Springer Praxis, Berlin Heidelberg, UK, p. 203-245.

Lopez-Gamundi, O.R., 1993, Pebbly mudstones in the Cretaceous Pigeon Point Formation, western California: A study in the transitional stages from submarine slumps to cohesive debris flows: Sedimentary Geology, v. 84, p. 37-50.

Lowe, D.R., 1979, Sediment gravity flows: Their classification and some problems of application to natural flows and deposits, in Doyle, L.J., and Pilkey, O.H., eds., Geology of Continental Slopes: Society of Economic Paleontologists and Mineralogists, Special Publication 27, p. 75-82. 1982, Sediment gravity flows: II. Depositional models with special reference to the deposits of high-density turbidity currents: Journal of Sedimentary Petrology, v. 52, p. 279-297.

1988 , Suspended-load fallout rate as an independent variable in the analysis of current structures: Sedimentology, v. 35, p. 765-776.

Lowe, D.R, and Guy, M., 2000, Slurry-flow deposits in the Britannia Formation (Lower Cretaceous), North Sea: a new perspective on the turbidity current and debris flow problem: Sedimentology, v 47, p. 31-70.

Lowe, D.R., and Lopiccolo, R.D., 1974, The characteristics and origins of dish and pillar structures: Journal of Sedimentary Petrology, v. 44, p. 484-501.

MacEachern, J.A., Pemberton, S.G., Bann, K.L., and Gingras, M.K., 2007, Departures from the archetypal inchnofacies: Effective recognition of physic-chemical stresses in the rock record, in MacEachern, J.A., Bann, K.L., Gingras, M.K., and Pemberton, S.G., eds., Applied Ichnology: Society of Economic Paleontologist and Mineralogists, Short Course 52, p. 65-93.

Maslin, Mark, Owen, Matthew, Day, Simon, and Long, David, 2004, Linking continental-slope failures and climate change: Testing the clathrate gun hypothesis: Geology, v. 32, p. 53-56. https://doi.org/10.1130/G20114.1

Mulder, Thierry, and Alexander, Jan, 2001, The physical character of subaqueous sedimentary density flows and their deposits: Sedimentology, v. 48 , p. $269-299$.

Mulder, Thierry, and Cochonat, Pierre, 1996, Classification of offshore mass movements: Journal of Sedimentary Research, v. 66, p. 43-57. Myrow, P.M., 1992, Pot and gutter casts from the Chapel Island Formation, southeast Newfoundland: Journal of Sedimentary Geology, v. 62, p. 992-1,007. 
Nardin, T.R., Hein, F.J., Gorsline, D.S., and Edwards, B.D., 1979, A review of mass movement processes, sediment and acoustic characteristics and contrast in slope and baseof-slope systems versus canyon-fan-basin floor systems, in Doyle, L.J., and Pilkey, O.H., eds., Geology of Continental Slopes: Society of Economic Paleontologists and Mineralogists, Special Publication 27, p. 61-73.

Nokleberg, W.J., Plafker, George, and Wilson, F.H., 1994, Geology of south-central Alaska, in Plafker, G., and Berg, H.C., eds., The Geology of Alaska: Geological Society of America, The Geology of North America, v. G-1, p. 311-366. Petter, A.L., and Steel, R.J., 2006, Hyperpycnal flow variability and slope organization on an Eocene shelf margin, central basin, Spitsbergen: American Association of Petroleum Geologists Bulletin, v. 90, p. 1,451-1,472.

Plafker, George, Nokleberg, W.J., and Lull, J.S., 1989, Bedrock geology and tectonic evolution of the Wrangellia, Peninsular, and Chugach terranes along the trans-Alaska crustal transect in the Chugach Mountains and southern Copper River basin, Alaska: Journal of Geophysical Research, v. 94, p. 4,255-4,295.

Plink-Bjorklund, Piret, Mellere, Donatella, and Steel, R.J., 2001, Turbidite variability and architecture of sand-prone, deep-water slopes: Eocene clinoforms in the central basin, Spitsbergen: Journal of Sedimentary Research, v. 71, p. 895-912.

Posamentier, H.W., and Allen, G.P., 1999, Siliciclastic Sequence Stratigraphy - Concepts and Applications: SEPM Concepts in Sedimentology and Paleontology \#7, Tulsa, OK, $210 \mathrm{p}$.

Posamentier, H.W., and Martinsen, O.J., 2011, The character and genesis of submarine masstransport deposits: Insights from outcrop and 3D seismic data, in Shipp, R.C., Weimer, P., and Posamentier, H.W., eds., Mass-Transport Deposits in Deepwater Settings: Society of Economic Paleontologists and Mineralogists, Special Publication 96, p. 7-38.

Posamentier, H.W, and Walker, R.G., 2006, Deep-water turbidites and submarine fans, in Posamentier, H.W., and Walker, R.G., eds.,
Facies Models Revisited: Society of Economic Paleontologists and Mineralogists, Special Publication 84, p. 397-520.

Reading, H.G., and Richards, M., 1994, Turbidite systems in deep-water basin margins classified by grain size and feeder system: AAPG Bulletin, v. 78, p. 792-822.

Rodine, J.D., and Johnson, A.M., 1976, The ability of debris freighted with coarse clastic material to flow on gentle slopes: Sedimentology, v. 23, p. 213-234.

Shipp, R.C., Weimer, Paul, and Posamentier, H.W., 2011, Mass-transport deposits in deepwater settings: An introduction, in Shipp, R.C., Weimer, P., and Posamentier, H.W., eds., Mass-Transport Deposits in Deepwater Settings: Society of Economic Paleontologists and Mineralogists, Special Publication 96, p. 3-6.

Stow, D.A.V., Reading, H.G., and Collinson, J.D., 1996, Deep seas, in Reading, H.G., ed., Sedimentary Environments, third edition, Backwell. Oxford, UK, 688 p.

Swenson, R.F., 2003, Introduction to Tertiary tectonics and sedimentation in the Cook Inlet basin, in Dallegge, T.A., compiler, 2001 Guide to the petroleum geology and shallow gas potential of the Kenai Peninsula, Alaska: Alaska Division of Geological \& Geophysical Surveys Miscellaneous Publication 128, p. 10-19.

Talling, P.J., Masson, D.G., Sumner, E.J., and Malgesini, Giuseppe, 2012, Subaqueous density flows: depositional processes and deposit types: Sedimentology, v. 59, p. 1,937-2,003.

Taylor, A.M., and Goldring, R., 1993, Description and analysis of bioturbation and ichnofabric: Journal of the Geological Society of London, v. 150, p. 141-148.

Trop, J.M., and Ridgway, K.D., 2007, Mesozoic and Cenozoic tectonic growth of southern Alaska: A sedimentary basin perspective, in Ridgway, K.D., Trop, J.M., Glen, J.M.G., and O'Neill, J.M., eds., Tectonic Growth of a Collisional Continental Margin: Crustal Evolution of Southern Alaska: Geological Society of America Special Paper 431, p. 55-94.

Trop, J.M., Szuch, D.A., Rioux, M., Blodgett, R.B., 2005, Sedimentology and provenance of 
the Upper Jurassic Naknek Formation, Talkeetna Mountains, Alaska: Bearings on the accretionary tectonic history of the Wrangellia composite terrane: Geological Society of American Bulletin, v. 117 , p. $570-588$.

Walker, R.G., 1975, Generalized facies models for resedimented conglomerates of turbidite association: Geological Society of America Bulletin, v. 86, p. 737-748.

Wartes, M.A., Decker, P.L., Herriott, T.M., and Helmold, K.P., 2015, Preliminary facies analysis of the lower sandstone member of the Upper Jurassic Naknek Formation, northern Chinitna Bay, Alaska, in Wartes, M.A., ed., Energyrelated studies during the 2014 field season, western Cook Inlet, Alaska: Alaska Division of Geological \& Geophysical Surveys Preliminary Interpretive Report 2015-5-8, p. 49-55. doi:10.14509/29463

Wartes, M.A., Herriott, T.M., Helmold, K.P., and Gillis, R.J., 2013, Preliminary stratigraphic interpretation of the Naknek Formation:
Evidence for Late Jurassic activity on the Bruin Bay fault, Iniskin Peninsula, lower Cook Inlet, in Gillis, R.J., ed., Overview of 2012 field studies: Upper Alaska Peninsula and west side of lower Cook Inlet, Alaska: Alaska Division of Geological \& Geophysical Surveys Preliminary Interpretive Report 2013-1H, p. 39-46. doi:10.14509/24851

Weimer, Paul, and Slatt, R.M., 2007, Deepwater reservoir elements: mass-transport deposits and slides, in Weimer, Paul, and Slatt, R.M., Petroleum geology of deepwater settings: AAPG Studies in Geology No. 57p. 419-455.

Wilson, F.H., Hults, C.P., Schmoll, H.R., Haeussler, P.J., Schmidt, J.M., Yehle, L.A., and Labay, K.A., comps., 2012, Geologic map of the Cook Inlet region, Alaska, including parts of the Talkeetna, Talkeetna Mountains, Tyonek, Anchorage, Lake Clark, Kenai, Seward, Iliamna, Seldovia, Mount Katmai, and Afognak: U.S. Geological Survey Scientific Investigations Map 3153, 76 p., 2 sheets, scale 1:250,000. 